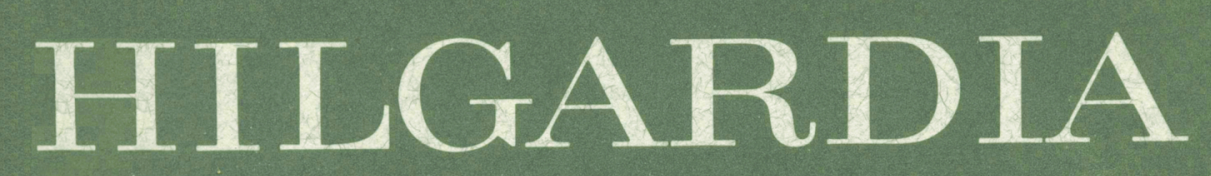

AJOURNAL OF AGRICULTURAL SCIENCE PUBLISHED BY THE CALIFORNIA AGR ICULTURALEXPERIMENT STATION

Volume 48, Number $1 \cdot$ January, 1980

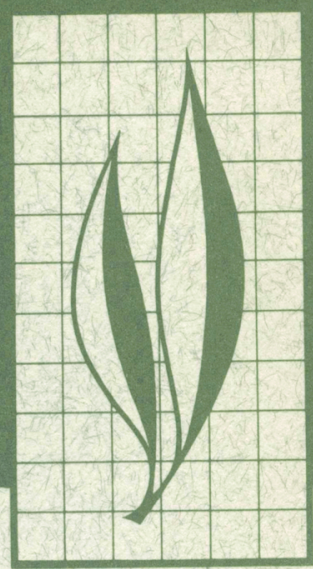

\title{
Phosphorus Removal from Wastewater Applied to Land
}

\author{
J. C. Ryden and P. F. Peatt
}




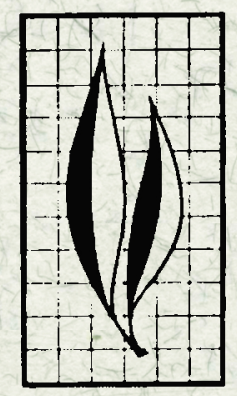

Low concentrations of phosphorus $(\mathrm{P})$ are desired in surface waters to minimize production of organic materials which cause problems in water use. The low $P$ concentrations characteristic of the soil solution suggest that soils represent an appreciable sink for $P$ in wastewaters applied to land. The mechanisms responsible for maintaining low (usually less than $0.5 \mathrm{mg} \mathrm{P}^{-1}$ soil-solution $\mathrm{P}$ concentrations and for control of the chemical mobility of $P$ in the soil profile appear in most cases, to involve a sorption reaction at soil surfaces with a hydrous oxide structure. Recent work has led to an interpretation of $P$ sorption by soils which has direct relevance to an understanding of $P$ removal from wastewater applied to land. Crops harvested at wastewater treatment sites, also represent a sink for added P. Phosphorus removal of $10 \%$ of that applied is typical, but 30 to $40 \%$ of the $P$ applied at a rate of 200 to $300 \mathrm{~kg} \mathrm{P} \mathrm{ha}^{-1} \mathrm{yr}^{-1}$ may be removed by harvested forage crops. Schemes of wastewater application to land involve either infiltration and percolation of the wastewater through the soil profile or overland flow. Most complete P removal is generally observed in infiltration-percolation schemes which permit maximum contact between wastewater and soil, and particularly if wastewater is applied to give a $\mathbf{P}$ input comparable to that under normal agricultural practice. Several mathematical models have been developed to predict $P$ movement through a soil profile, but the $P$ sorption data required are dificult to obtain. A simple mass-balance model is proposed, the $P$ sorption parameters of which are easily measured, are independent of soil type, and can be adjusted to account for the kinetics of $P$ sorption, thereby providing an estimate of the longevity of a treatment site for $P$ removal.

\section{THE AUTHORS:}

J. C. Ryden is Post-doctoral Student, and P. F. Pratt is Professor, Department of Soil and Environmental Sciences, Riverside. 


\section{Phosphorus Removal from Wastewater Applied to Land ${ }^{1}$}

\section{INTRODUCTION}

Phosphorus IN THE elemental FORM is highly reactive. Consequently, in natural environments, phosphorus is usually found in combination with oxygen as orthophosphate and occasionally as polyphosphate. Orthophosphate is found in a variety of mineral forms as well as in naturally occurring organic compounds, the latter being a result of its requirement for all forms of life. Phosphorus, therefore, must be present in available forms in all soils and waters if these are to be biologically productive. The production of large amounts of biological materials on land surfaces is usually considered desirable because these can be used for food, fiber, fuel, and building materials. However, in waters the production of large weights of biological materials usually causes undesirable effects. Thus, on agricultural land, materials containing phosphorus are added to increase biological production, whereas in most waters, attempts are made to keep the phosphorus concentration within low limits to avoid undesirable production of organic materials that cause problems in water use for municipal, industrial, agricultural, and recreational purposes.

Concentrations of total phosphorus in municipal wastewaters usually range from about 1.0 to $40 \mathrm{mg} 1^{-1}$ (Pound and Crites, 1973; Bouwer and Chaney, 1974; Hunter and Kotalik, 1976) depending on the phosphorus concentration of the input water and removal during treatment. Thomas (1973) used a concentration of $10 \mathrm{mg} \mathrm{P} 1^{-1}$ as a typical concentration. Most concentrations are usually less than $20 \mathrm{mg}^{-1}$.

In contrast, the concentration of dissolved inorganic phosphate in the soil solution of most soils is usually between 3 and $0.03 \mathrm{mg} \mathrm{1}^{-1}$ (Russell, 1973), with typical concentrations of a few tenths mg $1^{-1}$ (Larsen, 1967), and is usually a decreasing function with depth in the soil profile (Barber et al., 1963). These differences between the phosphate concentration ranges of wastewaters and the soil solution suggest a reduction in phosphate concentration as wastewater passes through a soil profile or contacts soil material in some other way. Such a reduction in phosphate concentration arises from various reactions that may occur between phosphate in the wastewater and soil mineral particles or other constituents of the soil solution. The extent of phosphate removal depends on the intensity of these reactions, the capacity of the soil materials to maintain them, and the time allowed for them to proceed. Harvested crops also serve as a sink for the added phosphorus and a certain amount cycles in organic materials (roots, stems and leaves) that are not harvested.

The objectives of this paper are to discuss the reactions of phosphorus with soils, to show their application to an understanding of the removal of phosphorus from wastewaters applied to soils and to assess the present status of our capabilities to predict the capacities of soils to remove phosphorus from such waters. The chemistry of phosphorus in soils, plants, and waters is complex, and the literature is voluminous. Consequently, this review will be restricted to that literature considered to be useful in developing an understanding of phosphorus removal in wastewater treatment systems. Other reviews and texts relating to soil phosphorus are available, including Larsen (1967), Holt et al. (1970), Russell (1973), Ryden et al. (1973), Tisdale and Nelson (1975), and Syers and Williams (1977). 


\section{REMOVAL MECHANISMS}

One of the following occurs to the phosphorus that is added to soils in fertilizers, wastes, or wastewaters; it is: 1) removed in harvested crops, 2) accumulated in the solid phase as organic compounds, sorbed ions, or discrete-phase inorganic compounds, 3) removed by soil erosion in both soluble and particulate forms, or 4) leached from the root zone in percolating water. In the following discussion the assumption is made that chemically-reactive phosphorus in soils is predominantly in the inorganic orthophosphate form, and that other forms of phosphorus ultimately convert to this form in the soil system (Blanchar and Hossner, 1969; Murrmann and Koutz, 1972; Enfield and Bledsoe, 1973; Ellis, 1973; Blanchar and Riego, 1976). Consequently, inorganic orthophosphate will be referred to hereafter as $P$.

The most important link in the nonbiological dynamics of $\mathrm{P}$ in soils is the reactions which occur between dissolved $P$ and other soil inorganics, both dissolved and particulate. Such reactions determine the extent of the reduction in solution $\mathrm{P}$ concentration subsequent to the addition of $P$ to soil, thereby influencing the availability of $P$ to crops and the extent of $P$ leaching through the soil profile.

The removal of $P$ from solution upon contact with soil may be described loosely as retention, a term that implies no distinct reaction type or mechanism. The more specific term, sorption, implies the retention of $\mathrm{P}$ at surfaces as opposed to its precipitation with other inorganic species from solution.

The understanding and explanation of the nature of $P$ retention have oscillated from those implying the dominance of sorption reactions to those which have relied exclusively on solubility and precipitation principles. An overview of the literature from the earliest published reports, however, suggests a consistency in the concept that $\mathrm{P}$ retention involves, at least in the greater part, a distinct chemical interaction (Warrington, 1868;
Russell and Prescott, 1916; Mattson, 1927; Ford, 1933; Low and Black, 1947; Cole and Jackson, 1950a, $b$; Hsu and Rennie, 1962; Hingston et al, 1967; Ryden and Syers, 1975a, c).

\section{Precipitation}

On the basis that $\mathrm{Al}$ and $\mathrm{Fe}$ phosphates could be formed and identified from solutions of similar composition to the soil solution, and from consideration of the solubility equilibrium of phosphate compounds, Haseman et al. (1950a, b) and Cole and Jackson (1950a, b) postulated that retention involved a precipitation reaction. Kittrick and Jackson (1955a, b; 1956) developed these concepts further. Using electron microscopy, Kittrick and Jackson (1955a) demonstrated the formation of ferric phosphate over the $\mathrm{pH}$ range of 4.3 to 7.0 during the treatment of hydrous ferric oxide with a $1 \mathrm{M}$ phosphate solution. The electron micrographs were taken to represent the formation of discrete-phase $P$ compounds. Based on these observations, and on the identification, by X-ray diffraction, of variscite and strengite prepared by solution precipitation techniques at elevated temperatures (Kittrick and Jackson, 1955b), it was proposed that these phosphate compounds represented the products of $P$ retention in neutral to acid soils.

Although Wild (1954) had shown that estimates of the $\mathrm{P}$ concentration of the soil solution showed little or no correspondence to solubility data for discrete $\mathrm{P}$ compounds, the work described above led to atiempts to correlate $P$ concentrations in aqueous soil extracts to the solubility isotherms of various $\mathrm{Al}, \mathrm{Fe}$ and $\mathrm{Ca}$ phosphates (Clark and Peech, 1955, 1960; Lindsay et al., 1959; Larsen and Court, 1961; Chakravarti and Talibudeen, 1962; Withee and Ellis, 1965; Murrmann and Peech, 1968; Larsen and Widdowson, 1970; Jensen, 1971; Talibudeen, 1974). Data (Fig. 1) 
drawn from several reports of the $P$ concentrations in aqueous extracts of a wide range of soil types with different fertilizer and liming histories, are plotted over the solubility isotherms for the range of phosphate compounds most commonly believed to occur in soils. This approach has been used extensively to postulate the existence of discrete phosphate compounds in soils and to suggest their importance in determining the chemical mobility of $\mathrm{P}$ in soil. The data in Fig. 1 show that the P concentrations in aqueous extracts, expressed as $\mathrm{pH}_{2} \mathrm{PO}_{4}$, ranged from approximately 5 to 6.5. These values of $\mathrm{pH}_{2} \mathrm{PO}_{4}$ indicate

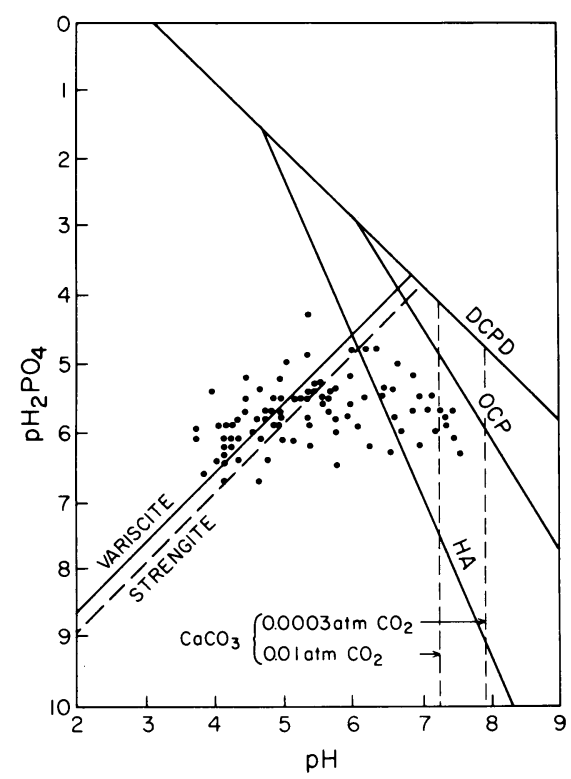

Fig. 1. Solubility isotherms for various phosphate compounds as a function of $\mathrm{pH}$, and data $(\bullet)$ for the $P$ concentration in soil solution extracts. Solubility isotherms are from Lindsay and Moreno (1960) and were calculated from values of solubility products and dissociation constants at $25^{\circ} \mathrm{C}$, assuming a Ca concentration of $5 \times 10^{-3} \mathrm{M}$. DCPD = dicalcium phosphate dihydrate; OCP = octacalcium phosphate; $\mathrm{HA}=$ hydroxyapatite. Data for the $\mathrm{P}$ concentration of soil solution extracts was taken from Clark and Peech (1955), Lindsay et al. (1959), Clark and Peech (1960), Larsen and Court (1961), Chakravarti and Talibudeen (1962), Withee and Ellis (1965), and Taylor and Gurney (1965). total $\mathrm{P}$ concentrations ranging from approximately 0.01 to $0.3 \mathrm{mg} \mathrm{P} 1^{-1}$ at $\mathrm{pH}$ 4 to concentrations as high as $0.69 \mathrm{mg} \mathrm{P}$ $1^{-1}$ at $\mathrm{pH}$ 8. The data, however, show no apparent $\mathrm{pH}$ dependence and little tendency to conform to any particular solubility isotherm. Furthermore the aqueous extracts were generally undersaturated with respect to all phosphate compounds over the $\mathrm{pH}$ range 5.5 to 6.5.

Further limitations of the solubility isotherm approach to an interpretation of the chemical mobility of $\mathrm{P}$ in soils were illustrated by the work of Taylor and Gurney (1962) and Bache (1963, 1964). Taylor and Gurney (1962) reported that, although the $\mathrm{P}$ and $\mathrm{Al}$ concentrations of aqueous extracts of an acid soil were compatible with the existence of variscite, treatment of the soil with very dilute acid resulted in the ion product falling below that expected for variscite. This observation demonstrated that the soil could maintain solution $\mathrm{P}$ concentrations lower than those predicted from the solubility isotherm for variscite, and that single point correspondence of $\mathrm{P}$ concentration data with a solubility isotherm is not a good criterion for the suggestion that a particular $\mathrm{P}$ compound controls the $\mathrm{P}$ concentration of the soil solution. A similar limitation to the use of solubility data was also demonstrated by Bache (1963) who showed that the solubility of variscite and strengite was congruent only below $\mathrm{pH}$ values of 3.1 and 1.4 , respectively. It was concluded that only highly-crystalline forms of variscite and strengite, the formation of which is improbable in soils (Lindsay et al, 1962), are likely to conform to thermodynamic solubility criteria.

In recently fertilized soils, however, it is well accepted that the $\mathrm{P}$ concentration and low $\mathrm{pH}$ of the solution in the vicinity of a fertilizer granule ( $4.0 \mathrm{M}$ and 1.48 , respectively, at the metastable triple point of mono- and di-calcium phosphate; Huffman and Taylor, 1963), are influential in the formation of a wide variety of discrete phosphate compounds by reaction with soil components (Lind- 
say et al., 1962; Huffman, 1969). Lindsay et al. (1962) identified at least thirty different compounds after soils and soil components had been reacted at a high solution: solid ratio with saturated solutions of five different fertilizer salts. Dominant products were complex phosphates of $\mathrm{Fe}, \mathrm{Al}$ and $\mathrm{Ca}$ in neutral to acid soils and calcium phosphates in calcareous soils. All compounds, however, supported higher $\mathrm{P}$ concentrations than the corresponding soils, ranging from 62 $\mathrm{mg} 1^{-1}$ for the least soluble $\mathrm{Fe}$ and $\mathrm{Al}$ phosphates. It is also probable that the $P$ compounds formed in these studies were short-range order (X-ray amorphous), as has been suggested by the work of Veith and Sposito (1977a). The solubility products of such compounds are almost certainly considerably greater than those of crystalline compounds which themselves in many cases maintain higher solution $\mathrm{P}$ concentrations than those observed for soil-solution extracts (Fig. 1).

The observations discussed above strongly suggest that the persistence of fertilizer reaction products in soils is unlikely (Huffman and Taylor, 1963). This conclusion is also supported by the work of Bache (1964), who showed that hydrous oxides of $\mathrm{Fe}$ and $\mathrm{Al}$ can maintain very much lower $P$ concentrations, by a sorption reaction, than those maintained by variscite and strengite. In the case of highly fertilized soils, however, fertilizer-reaction products may persist for a sufficiently long period to allow for recrystallization to produce more stable $P$ compounds (Lindsay et al., 1959, 1962; Taylor et al., 1963; Talibudeen, 1974) with solubilities compatible with the $\mathrm{P}$ concentration of the soil solution. Even if more stable fertilizer-reaction products eventually form in soils, it is unlikely that they will control the chemical mobility of $\mathrm{P}$ in the soil as a whole, as was indicated by the work of Murrmann and Peech (1969) and Jensen (1971).

Although discrete $\mathrm{P}$ compounds may form in fertilized soils, the conditions leading to their formation are unlikely to exist in soils to which wastewaters are being applied. Consequently, it is even more unlikely that solubility isotherms will provide a reliable basis for an understanding of the chemical mobility of $\mathrm{P}$ in soils to which wastewater is applied. It is such an understanding that is essential to the evaluation of the potential of a soil for $\mathrm{P}$ removal from wastewater.

Over recent years sorption models have been favored as a basis for understanding the chemical mobility of $P$ in soils. Although there is essentially no difference between the chemical forces involved in the precipitation of a particular compound and those holding an ion at a comparable sorbing surface (de Boer, 1950), sorption requires that as the process continues the structure of the sorbent remains essentially unchanged, whereas its surface activity changes appreciably. Consequently, concentrations maintained in solution at high sorbent saturation will be greater than those at low saturation. In contrast, precipitation implies a constant surface activity. This distinction between sorption and precipitation in the case of $\mathrm{P}$ retention by soils, has been clearly demonstrated by data presented by Hsu (1964). In fact, in most studies in which $\mathrm{P}$ has been added to soils in solution form, as would be the case for much of the $P$ present in wastewaters, the removal of $P$ from solution appears to fit the conditions of a sorption reaction specified above (Olsen and Watanabe, 1957; Rennie and McKercher, 1959; Hsu, 1964; Bache and Williams, 1971; Holford et al, 1974; Ryden et al., 1977a).

As indicated above, the extent of sorption is a function of the solution $P$ concentration. Therefore, one of the consequences of a sorption reaction with respect to the application of wastewater to soil is that added $\mathrm{P}$ should move into the soil and develop a diffuse boundary between the enriched and non-enriched zones. In contrast, if a compound of definite solubility was being formed, a very much more abrupt boundary would be expected. In field studies, a diffuse boundary has invariably been observed (Pratt et al., 1956; Kardos and Hook, 1976), indicating the importance of sorption as a P-removal mechanism as 
waters containing $\mathrm{P}$ pass through the profile.

\section{Sorption}

Sorption surfaces in soils. Numerous studies have been conducted to determine the nature of surfaces of importance in the sorption of $\mathrm{P}$ by soils (Leaver and Russell, 1957; Williams et al., 1958; Saunders, 1965; Syers et al., 1971; Vijaychandran and Harter, 1975). All have pointed to the importance of secondary $\mathrm{Fe}$ and $\mathrm{Al}$ oxides and hydrous oxides, particularly those with short-range order (amorphous) character (Williams et al., 1958; Saunders, 1965; Syers et al., 1971).

Similar conclusions can be drawn from data relating to the amounts of $P$ sorbed at a particular solution $P$ concentration by various mineral components known to exist in soils. Such data have been tabulated by one of these authors and presented elsewhere (Syers and Williams, 1977). In general, crystalline $\mathrm{Fe}$ and $\mathrm{Al}$ hydrous oxides (e.g., hematite and gibbsite) sorb five to ten times more $\mathrm{P}$ than crystalline aluminosilicates or calcium carbonates. In contrast, shortrange order components, such as Fe oxide gels, sorb 10 to one hundred times more $\mathrm{P}$ than their crystalline counterparts and approaching 1000 times more than crystalline aluminosilicates and calcium carbonates.

A considerable proportion of $\mathrm{Fe}$ and Al hydrous oxides in weakly to moderately weathered soils has shortrange order character (Mitchell et al., 1964). Consequently, the importance of such materials in $\mathrm{P}$ sorption by soils is likely to eclipse that of crystalline aluminosilicates and calcium carbonates. Even at the higher $\mathrm{pH}$ of calcareous and alkaline soils the presence of short-range order hydrous oxides, particularly if present as coatings, may reduce to minor importance the contribution of calcium carbonate to P sorption by such soils, as was demonstrated for calcareous sediments by Shukla et al. (1971) and for calcareous soils by Holford and Mattingly (1975a). Further- more, Holford and Mattingly (1975b), using naturally occurring calcium carbonate which contained 0.1 to $0.3 \% \mathrm{Fe}$, suggested that $\mathrm{P}$ sorption could be predominantly localized on the "iron oxide" impurities. The importance of calcium carbonate, however, in producing sufficiently high $\mathrm{Ca}$ concentrations in the soil solution to induce precipitation of $\mathrm{P}$, should not be overlooked (Holford and Mattingly, 1975b), particularly in relation to wastewaters with dissolved inorganic $\mathrm{P}$ concentrations in excess of 10 $\mathrm{mg} 1^{-1}$.

The distribution of $\mathrm{P}$ sorbing components in soils will also affect their capacity to remove $\mathrm{P}$ from solution. Hydrous oxides of $\mathrm{Fe}$ and $\mathrm{Al}$ have frequently been shown to occur as coatings on the clay mineral surfaces of a wide range of field soils (Shen and Rich, 1962; Jackson, 1963; Tweneboah et al., 1967; Deshpande et al., 1968; Greenland et al., 1968; Roth et al., 1969; Brown and Newman, 1973; Kirkman, 1973). The existence of hydrous oxides as coatings on other soil mineral surfaces increases their effective surface area, and emphasizes further the minor role that crystalline aluminosilicates are likely to have in the sorption of $\mathrm{P}$ by soils. Consequently, the hydrous oxide surface has been frequently used as a model surface for the evaluation of the nature of $P$ sorption by soils (Hsu and Rennie, 1962; Bache, 1964; Hingston et al., 1968, 1972; Rajan et al., 1974; Ryden and Syers, 1975).

Nature of $\mathbf{P}$ sorption. As the removal of $\mathrm{P}$ from solution by soils appears, in most cases, to conform to a sorption reaction, a convenient way to represent such data is in the form of a $\mathrm{P}$ sorption isotherm. The latter describes the relationship, at constant temperature, between the amount of $\mathrm{P}$ sorbed by the sorbent and that maintained in solution. One of the advantages of expressing data in this way is that quantitative interpretations of the data can be made using adsorption equations.

The sorption equations most frequently used to interpret $\mathrm{P}$ sorption data have 
been the Freundlich equation (Russell and Prescott, 1916; Kurtz et al., 1947; Kuo and Lotse, 1974; Fitter and Sutton, 1975), and the Langmuir equation (Cole et al., 1953; Olsen and Watanabe, 1957; Shapiro and Fried, 1959; Rennie and McKercher, 1959; Hsu and Rennie, 1962; de Haan, 1965; Muljadi et al., 1966; Bache and Williams, 1971; Syers et al., 1973a; Schwertmann and Knittel, 1973; Rajan, 1975a, Ryden et al., 1977a). Of these equations, the Langmuir is the most useful in that its constants are nonempirical. A plot of data using one of the linear forms of the Langmuir equation (Brunauer et al., 1966; Syers et al., 1973a) permits the determination of the sorption maximum and a sorptionenergy constant which can be related to the free energy $(\Delta G)$ of sorption (Graham, 1953). Although Langmuir (1918) originally developed this equation to describe the sorption of gases by solid systems, its extention to sorption from aqueous solution has been discussed by Giles (1970) who concluded that its application to such systems should be equally valid. A similar conclusion may be drawn from a discussion by de Boer (1953).

Early applications of the Langmuir equation to $\mathrm{P}$ sorption by soils and soil components (Olsen and Watanabe, 1957; Rennie and McKercher, 1962; Hsu and Rennie, 1962) generally covered a range of solution $P$ concentrations, subsequent to sorption, that were considerably greater than those commonly found in the soil solution. These studies suggested that although $\mathrm{P}$ sorption appeared to be described by the Langmuir equation, deviations from a single linear relationship occurred at solution $\mathrm{P}$ concentrations in excess of $15 \mathrm{mg} 1^{-1}$. Shapiro and Fried (1959) using soils, and de Haan (1965) using various aluminosilicates, showed that curvilinear Langmuir relationships could be transformed into two linear relationships, suggesting that $\mathrm{P}$ sorption involved at least two different mechanisms, reactions or populations of sorption sites. Muljadi et al. (1966), using an inspection technique, split isotherms for $\mathrm{P}$ sorption by several aluminous components into three portions or "regions" each of which corresponded to a distinct solution $\mathrm{P}$ concentration range (region $\mathrm{I}<3.1 \mathrm{mg} 1^{-1}$; II, 3.1 to $31 \mathrm{mg} 1^{-1}$; III, $31-3100 \mathrm{mg}$ $\left.1^{-1}\right)$. Regions I and II were described by Langmuir equations, although the constant relating to $\Delta \mathrm{G}$ was very similar for each region. Greater differences would have been expected if the inspection technique had reliably split the composite isotherms.

Syers et al. (1973a) demonstrated that the Langmuir equation itself, and the two linear relationships given by experimental data for $\mathrm{P}$ sorption by contrasting Brazilian soils, could be used to differentiate two regions of apparently different sorption energy over a solution $\mathrm{P}$ concentration range up to $14 \mathrm{mg} 1^{-1}$. After correction for the interaction of the sorption constants of one region with those of the other, each region was described by a distinct Langmuir equation. Very similar results have been presented by Holford et al. (1974) and Holford and Mattingly (1975a), for contrasting English and Australian soils.

For a given region the sorption energy constants obtained by both Syers et al. (1973a) and Holford et al. (1974) were comparable. This was particularly true for the second sorption region corresponding to solution $\mathrm{P}$ concentrations greater than approximately $2 \mathrm{mg} 1^{-1}$. Furthermore, the sorption energy constants of the second region were also of a similar order to those obtained by Muljadi et al. (1966). The similarities in sorption energy constants observed for such a wide range of soils and soil components strongly suggest that the same reaction mechanisms and sorption sites were involved in $P$ sorption by each soil and component.

The above discussion indicates that $\mathrm{P}$ sorption by soils is described by at least two distinct Langmuir equations over the solution $\mathrm{P}$ concentration range of importance in soils, and some workers (Syers et al., 1973a; and Chen et al., 1973a; Schwertmann and Knittel, 1973) have suggested a third. Consequently, an evaluation of $\mathrm{P}$ sorption using the Langmuir equation requires a test for data fit over 
the complete solution $\mathrm{P}$ concentration range starting as close to the origin as is experimentally feasible. Holford et al. (1974) and Ryden et al. (1977a) have also pointed out the need to include the amount of $\mathrm{P}$ already extant on the sorbing surface. Such detailed resolution of $P$ sorption isotherms, in the first instance at least, is essential because each experimentally determined point on the isotherm represents the sum of $P$ sorption at each sorption energy. Failure to apply the Langmuir equation over the complete solution $\mathrm{P}$ concentration range, and to correct for the amount of $\mathrm{P}$ already in the soil, have led to the somewhat inconclusive interpretations of $\mathrm{P}$ sorption data and to criticism of the application of the Langmuir equation to describe $P$ sorption by soils (Gunary, 1970; Bache and Williams, 1971).

Recent work (Ryden and Syers, 1975, 1977a, b, Ryden et al., 1977a, b, c; McLaughlin, et al., 1977), in which the above limitations have been avoided, has shown that isotherms for $\mathrm{P}$ sorption by contrasting fertilized and unfertilized soils and various hydrous $\mathrm{Fe}$ oxides, are described by three Langmuir equations over a final solution $\mathrm{P}$ concentration range of zero to greater than $20 \mathrm{mg}^{-1}$. Each equation accounted for at least $80 \%$ of the sorption occurring over its operational solution $\mathrm{P}$ concentration range and was virtually independent of the sorbent used when the amount sorbed was expressed as a proportion of the sorption maximum. These observations, coupled with other data relating to the surface charge, the effects of $\mathrm{pH}$, ionic strength and cation species on the extent of $\mathrm{P}$ sorption, and the ease of isotopic exchange and desorption of sorbed $\mathrm{P}$, demonstrated that each Langmuir equation described $\mathrm{P}$ sorption by a specific mechanism. Sorption by two of these mechanisms, each described by a particular Langmuir equation, resulted in the chemisorption of $\mathrm{P}$ at a hydrous oxide surface, and accounted for $80 \%$ of sorption below solution $\mathrm{P}$ concentrations of approximately $0.2 \mathrm{mg} 1^{-1}$. Above this concentration, an increasing proportion of $\mathrm{P}$ sorption was described by the third Langmuir equation which reflected, and was shown to arise from, a more-physical sorption reaction which was reversible upon a reduction in the solution $\mathrm{P}$ concentration (Ryden and Syers, 1977a). Furthermore, where data can be compared, the sorption energy constants obtained by Ryden and Syers (1975) are very similar to those obtained by previous workers using a wide variety of soils and soil components (Olsen and Watanabe, 1957; Muljadi et al., 1966; Chen et al., 1973a; Syers et al., 1973a; Holford et al., 1974). This is particularly true for the sorption energy constants relating to sorption at higher solution $\mathrm{P}$ concentrations where more physical sorption is dominant. The general applicability of this sorption model to a wide variety of surface soils, subsoils and hydrous ferric oxides, suggests that it may form the basis of a useful approach to the evaluation of the potential of soils for the removal of $P$ from wastewaters, as will be discussed later.

The conclusions outlined above are also in accord with the "three-compartment" (A-B-C) model developed by Barrow and Shaw (1974 and references within) from consideration of the kinetics of $P$ sorption. Compartment $A$ represented the soil solution, B a weakly sorbed P (c.f., morephysically sorbed $\mathrm{P}$ ) and $\mathrm{C}$ a strongly sorbed P (c.f., chemisorbed P).

Conformity to the Langmuir equation of data for the removal by soils of $P$ from solution does not constitute irrefutable proof that a sorption reaction is involved (Brunauer et al., 1966; Veith and Sposito, 1977). Additional data that have recently been presented relating to the charge, $\mathrm{pH}$ and ionic strength relationships of $\mathrm{P}$ uptake (Rajan et al., 1974; Rajan, 1976; Ryden $e$ al., 1977a, c) and to the ease of release (desorption) and isotopic exchangeability of $\mathrm{P}$ removed from solution (Ryden and Syers, 1977a) can only be explained if a sorption reaction is postulated not only for the uptake of $\mathrm{P}$ by soils but also by hydrous oxides.

Some studies have suggested that at solution $\mathrm{P}$ concentrations considerably higher than those present in the soil solution, but within the range of concentrations expected for wastewaters, a 
secondary precipitation reaction may occur. When precipitation occurs as an adjunct to sorption, a dramatic increase in the slope of the sorption isotherm will be observed (Olsen and Watanabe, 1957). Holford and Mattingly (1975b) demonstrated that in the case of $\mathrm{P}$ sorption by various Jurassic limestones, precipitation of $\mathrm{P}$, apparently as octacalcium phosphate, can occur from solutions with initial $\mathrm{P}$ concentrations in excess of approximately $10 \mathrm{mg}^{-1}$. Similar conclusions were drawn by Cole et al. (1953) and Griffin and Jurinak (1973) for the sorption of $\mathrm{P}$ by pure calcium carbonate and calcite, respectively. In the case of allophanic clay minerals. Rajan (1975a,b) has also shown that $\mathrm{P}$ may continue to be removed from solution by disruption of the sorbing surface and concommitant displacement of structural silicon. Although such a mechanism cannot be considered to be exactly the same as precipitation, the concept is similar to the observation by Low and Black (1947) that at high solution $\mathrm{P}$ concentrations, $\mathrm{P}$ may be retained by precipitation with $\mathrm{Al}$ dissociated from kaolinite.

Secondary precipitation appears to occur only at high solution $\mathrm{P}$ concentrations, generally in excess of $10 \mathrm{mg} 1^{-1}$, and may not be observed at all even when the contacting solution is supersaturated with respect to a particular $\mathrm{P}$ compound (Holford et al., 1974). Consequently, sorption would appear to be the dominant mechanism for removal of $P$ from solutions in contact with soils. As discussed previously, precipitation reactions are only expected in the vicinity of fertilizer particles, or possibly in cases where high $\mathrm{Ca}$ concentrations are present in the soil solution. The latter are only expected in the case of alkaline soils, soils with free $\mathrm{CaCO}_{3}$, or where $\mathrm{Ca}$ is being added to the soil at the same time as $\mathrm{P}$, as may occur in the case of some wastewaters. In all other cases, the general applicability of a sorption model suggests a useful approach to the evaluation of the potential of soils for the removal of $P$ from wastewaters.

Most of the concepts outlined above were developed using aqueous solutions of various amounts of salts such as $\mathrm{KCl}$,
$\mathrm{NaCl}$, or $\mathrm{CaCl}_{2}$. The composition of wastewater is much more complex (Ames, 1970), and it is possible that some of its properties may affect the nature and extent of $\mathrm{P}$ sorption. Of these compositional properties, the relatively high $\mathrm{pH}$ (frequently above 8) and the presence of organic anions are most likely to affect $P$ sorption (Deb and Datta, 1967; Nagarajah et al., 1968, 1970; Hingston et al., 1972; Ryden et al., 1977a), both of which are expected to decrease P sorption. Data reported by Ryden and Syers (1975b), and unpublished data of the latter authors, show that the extent of $P$ sorption does in fact decrease as a result of these differences in composition, the most important of which is the elevated $\mathrm{pH}$. The nature of the reaction, however, appears to remain the same. Consequently, the principles of the sorption models described in this discussion are expected to be equally applicable to an understanding of the sorption of $\mathrm{P}$ by soils in wastewater treatment systems.

Time dependence of $\mathbf{P}$ sorption and reaction rate. Although in most cases the retention of $\mathrm{P}$ by soils and soil components is consistent with a sorption reaction, a reaction involving only true adsorption would imply a rapid reaction rate and a well-defined equilibrium. The sorption of $\mathrm{P}$ by soils and soil components, however, is characterized by an initially fast reaction followed by a slow reaction which frequently does not attain a true equilibrium (Rennie and McKercher, 1959; Hsu, 1964; Fox and Kampreth, 1970; Evans and Syers, 1971; Rajan and Fox, 1972; Barrow and Shaw, 1974; Enfield, 1974; Ryden et al., 1977b). Furthermore, changes in the properties of sorbed $\mathrm{P}$, such as decreases in the ease of desorption and isotopic exchange of sorbed $\mathrm{P}$, are attendant to this slow equilibration (Dean and Rubins, 1947; McAuliffe et al., 1947; Hayes et al., 1952; Carritt and Goodgal, 1954; Kafkafi et al., 1967; Evans and Syers, 1971; Munns and Fox, 1976; Ryden and Syers, 1977a).

It seems reasonable to suggest that the initial rapid reaction can be attributable to a true adsorption reaction (Rennie and 
McKercher, 1959; Hsu, 1964; Munns and Fox, 1976) and evidence to this effect based on chemical fractionation of sorbed $P$ has been presented recently by Ryden et al. (1977b) and McLaughlin et al. (1977). The origin and nature of the slow reaction, however, has received little attention. Larsen (1967), Larsen and Widdowson (1971), and Talibudeen (1974) have suggested that the slow reaction involves the transformation of sorbed $P$ to discrete $\mathrm{P}$ compounds. Evidence for such a mechanism has been presented by Chen et al. (1973 a, b), who observed the long-term product of the reaction between solutions of various $\mathrm{P}$ concentrations and aluminous surfaces to be short-range order aluminum phosphate.

Analysis of isotherms, using the Langmuir equation, for the sorption of $\mathrm{P}$ by soils and hydrous $\mathrm{Fe}$ oxides during various time periods has shown that time dependent sorption of $\mathrm{P}$ is associated with an appreciable shift of $\mathrm{P}$ from a more physically sorbed form to a chemisorbed form (Ryden et al., 1977b; McLaughlin et al., 1977). Associated data, based on a chemical fractionation of sorbed $\mathrm{P}$ developed by Williams et al. (1967), demonstrated that the shift in the forms of sorbed $P$ was accompanied by a decrease in the amount of surface-bound $(0.1 \mathrm{M} \mathrm{NaOH}$ extractable) $\mathrm{P}$, implying the absorption of initially adsorbed P. Such a process, which was shown to be associated with the presence of "structurally-porous" short-range order hydrous oxides, allows not only for the slow increase in the number of sorption sites, but also for the decreases in the ease of isotopic exchange and desorption.

The model summarized above is again in accord with the three-component model developed by Barrow and Shaw (1974) and outlined in the previous section. With increasing time, $\mathrm{P}$ was transferred from compartment B to $C$. The kinetic basis of the model developed by Barrow and Shaw (1974) provides a useful approach to a generalized description of the kinetics of the transfer of $P$ from compartment B to C (i.e., the shift from more-physically adsorbed $\mathrm{P}$ to chemically ad- and absorbed P) the regeneration of sorption sites and the potential change in solution $\mathrm{P}$ concentration.

For a wide range of south Australian soils the transfer of $\mathrm{P}$ from compartment $\mathrm{B}$ to compartment $\mathrm{C}$ was described by equation [1]:

$$
(1-\alpha)=(\mathrm{kt}+1)^{-\mathrm{b}}
$$

where $\alpha$ is the fraction of sorbed $\mathrm{P}$ in compartment $\mathrm{C},(1-\alpha)$ is the fraction of sorbed $\mathrm{P}$ remaining in compartment $\mathrm{B}, \mathrm{t}$ is the time of contact between added $P$ and the soil, $\mathrm{b}$ is a constant, and $\mathrm{k}$ is a temperature dependent coefficient (equation [2]) related to the activation energy of the reaction involved in the transfer of $\mathrm{P}$ from compartment $\mathrm{B}$ to $\mathrm{C}$,

$$
k=A \exp ^{-E / R T}
$$

where $A$ is a constant, $R$ is the gas constant, $\mathrm{T}$ is the absolute temperature, and $E$ is the activation energy.

Barrow and Shaw (1974) used the phrase "relative effectiveness" (Fig. 2) to describe the term $(1-\alpha)$ in equation [1]. The value of $(1-\alpha)$ related to the proportion of added $P$ which remained effective for plant growth, the proportion which remained in equilibrium with the soil solution, or the proportion which remained

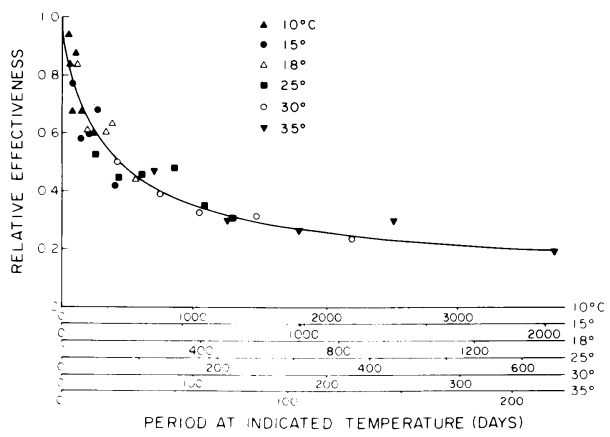

Fig. 2. Effect of period and temperature of incubation of soil plus phosphate on the effectiveness of added $P$ for plant growth, the change in the amount of $P$ in equilibrium with the soil solution, and the change in the amount of desorbable and isotopically exchangeable $P$, relative to the freshly applied phosphate (Reprinted from Barrow and Shaw, 1974, p. 358, by courtesy of Marcel Dekker, Inc.). 
desorbable or isotopically exchangeable. When the data presented by Ryden and Syers (1977) and Ryden et al. (1976, $1977 \mathrm{~b})$ are considered in relation to Fig. 2 , it follows that $(1-\alpha)$ also relates to the decrease in water-extractable $\mathrm{P}$ with time and to the proportion of sorption sites that are regenerated as a result of the shift of $\mathrm{P}$ from the more-physically adsorbed form through to the chemically absorbed form.

The curve described by equation [1] shows that as the period of contact increases the rate of transfer of $P$ from compartment B to $C$ decreases (Fig. 2). Equation [1] also implies that the proportionate change is independent of the amount of $P$ added. This was also found to be true for the proportionate change in the amount of more-physically sorbed $P$ present in soils to which $\mathrm{P}$ had been added either in solution or as calcic superphosphate (Ryden et al., 1976).

The effect of water content on the relationship in Fig. 2 was small except at very low water contents $(<10 \%)$. This was taken to suggest that the diffusion of $\mathrm{P}$ through the solution phase was not rate limiting and that the slow reaction occurred at the original sorption site. In contrast the reaction rate was markedly affected by temperature (Fig. 2), as was also observed by Gardner and Jones (1973), and increased approximately three-fold for each $10^{\circ} \mathrm{C}$ rise in temperature. Each of these effects evaluated and summarized by Barrow and Shaw (1974) are consistent with the movement of $\mathrm{P}$ from a more-physically sorbed form to a chemisorbed form involving a diffusive penetration of $\mathrm{P}$ into amorphous soil components (Ryden et al., 1977b; McLaughlin et al., 1977).

Possibly one of the most important features of this kinetic model is that the rate of transfer of $P$ from compartment $B$ to $C$, and by inference the mechanism involved, was essentially the same for all the soils used. This was also found to be the case for the range of fertilized and unfertilized soils studied by Ryden $e t$ al. (1976). This similarity in the nature and rate in $\mathrm{P}$ sorption for a wide variety of soils and moisture contents, suggests a potentially useful application in the modelling of $\mathrm{P}$ sorption by soils to which $P$ is added in wastewaters.

\section{Crop removal}

In most cropped soils the application of $\mathrm{P}$ increases growth of plants. However, as more $\mathrm{P}$ is accumulated, i.e., excesses are added, negative effects are sometimes found. These decreased yields that result from excess available $P$ in the soil are indirect effects of $P$ on the availability of copper, iron and zinc and are referred to as nutrient imbalances (Bingham, 1966; Olsen, 1972; Lindsay, 1973; Baker and Chesnin, 1975). Corrections of these imbalances can be made by soil or foliar applications of the needed elements.

The removal of $\mathrm{P}$ in harvested crops depends on the yield and the P concentration in the harvested material, which in turn are dependent on the crop, soil, climate and management factors including the amount of $\mathrm{P}$ added to the soil. Typically, the harvested portions of annual crops contain only $10 \%$ or less of the $P$ added during the season in which the crop was grown, but recoveries as high as 50 to $60 \%$ are possible (Russell, 1973). Recovery is generally low not only because the soil reacts with the added $\mathrm{P}$ to make it less available, but also because plants absorb considerable amounts of $\mathrm{P}$ from soil supplies including the residues from applications in previous years. Thus, the total removal per year as a fraction of the total added per year is more important than the recovery of that added during the period the crop is grown.

Amounts of $\mathrm{P}$ removed by the harvested portions of agronomic and vegetable crops vary from about $11 \mathrm{~kg} \mathrm{ha}^{-1}$ $\mathrm{yr}^{-1}$ for sugar beets, peanuts and oats to about 62 to $74 \mathrm{~kg} \mathrm{ha}^{-1} \mathrm{yr}^{-1}$ for forage crops (Tisdale and Nelson, 1975). Typical data are summarized in Table 1. Kardos and Hook (1976) reported that $33 \mathrm{~kg}$ $\mathrm{ha}^{-1} \mathrm{yr}^{-1}$ were removed during a 5-year period of a small grain-corn-hay rotation, that 31 to $41 \mathrm{~kg} \mathrm{ha}^{-1} \mathrm{yr}^{-1}$ were removed by corn silage during a 6-yr period, and that removal by reed canary grass during an 11 -yr period averaged $45 \mathrm{~kg} \mathrm{ha}^{-1} \mathrm{yr}^{-1}$ 
from lands that were irrigated with reclaimed municipal wastewater. They found that removal by crops averaged 34,59 and $22 \%$, respectively, for the small grains-corn-hay rotation, the continuous corn silage and the reed canary grass. The amount of $\mathrm{P}$ added to the grass was about three times greater than that added to the other cropping systems.

Unpublished data ${ }^{2}$ for a cropping system in which sudangrass was grown in the summer and barley was grown in the winter, both harvested for forage, showed $P$ removal of 85 to $96 \mathrm{~kg} \mathrm{ha}^{-1} \mathrm{yr}^{-1}$. For an input of $232 \mathrm{~kg} \mathrm{ha}^{-1} \mathrm{yr}^{-1}$ the removal represented 37 to $41 \%$; for an input of $463 \mathrm{~kg} \mathrm{ha}^{-1} \mathrm{yr}^{-1}$, the removal was reduced to about $20 \%$ of the input, illustrating the point that $\mathrm{P}$ removal in harvested materials, as a fraction of that added, decreases as the amount of $\mathrm{P}$ added increases.

Kutera (1975) reported that V. Semyonov found that cultivation of poplar trees in a sandy soil in lysimeters removed from 26 to $40 \mathrm{~kg} \mathrm{P} \mathrm{ha}^{-1} \mathrm{yr}^{-1}$ at wastewater treatment rates that added about 26 $\mathrm{kg} \mathrm{P} \mathrm{ha} \mathrm{yr}^{-1}$. At the highest rate of wastewater treatment, $70 \mathrm{~kg} \mathrm{ha}^{-1} \mathrm{yr}^{-1}$ was removed by this crop. The $\mathrm{P}$ removed in drainage water was about $1 \mathrm{~kg} \mathrm{ha}^{-1}$ $\mathrm{yr}^{-1}$ with 30 surface $\mathrm{cm}$ of wastewater $\mathrm{yr}^{-1}$ and 4.5 to $6.8 \mathrm{~kg} \mathrm{ha}^{-1} \mathrm{yr}^{-1}$ with 160 surface $\mathrm{cm}$ of wastewater $\mathrm{yr}^{-1}$.

Amounts of $\mathrm{P}$ removed by crops can range by an order of magnitude and are higher with forage crops than with most other crops. Maximum removal of $P$ is generally achieved for crops that have a large rooting volume, such as grasses (Table 1). Such crops are well suited to wastewater treatment sites in that they can be cut immediately after the period of most vigorous growth, possibly allowing two or more cuts per season. Where double cropping during a long season is possible, removal can be nearly double that where only one crop can be grown.

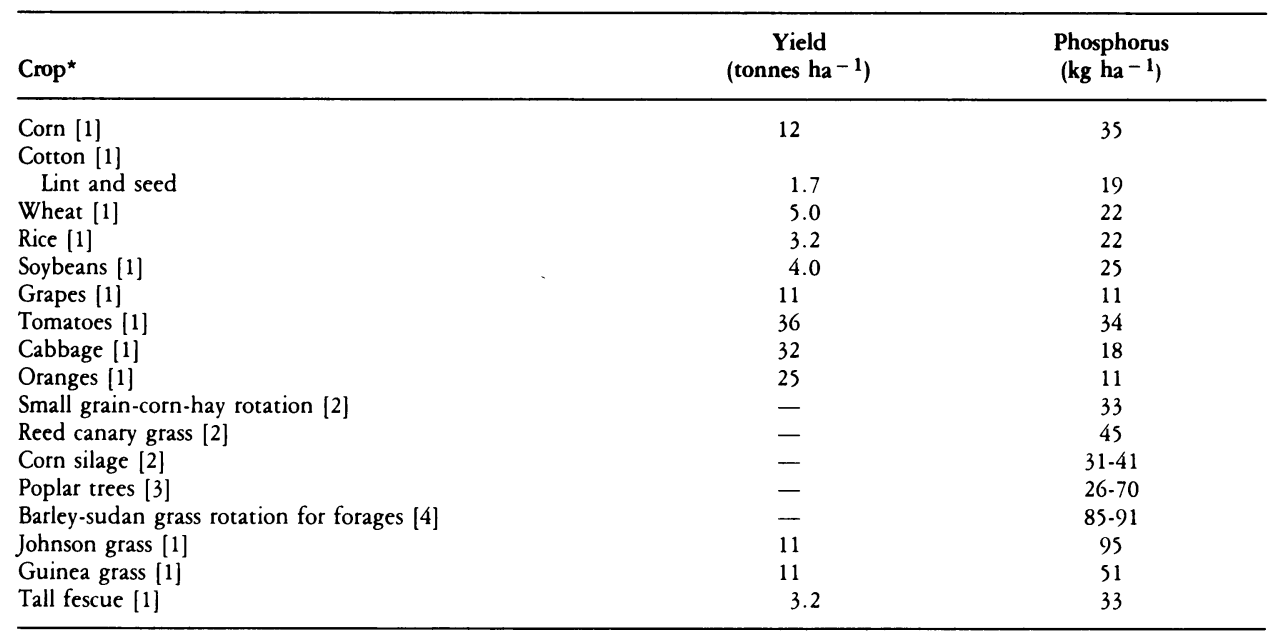

*[1] Agricultural Waste Management Field Manual (1975); [2] Kardos and Hook (1976); [3] Kutera (1975); [4] Unpublished data of Pratt and Davis, University of California, and USDA-ARS, Riverside. 


\section{PHOSPHORUS REMOVED IN LAND TREATMENT SYSTEMS}

Thomas (1973) has pointed out that the effects of land treatment systems on plant growth, soils and groundwaters have received scant attention. Furthermore, technical questions relating to the behavior of $\mathrm{P}$ during wastewater application to land have been posed only recently. Consequently, little has been reported on $\mathrm{P}$ retention by soils in land application systems. A convenient way to develop answers to some of these questions for specific systems is to develop concepts relating to the factors which determine the rate and extent of the leaching of $\mathrm{P}$ from soils.

\section{Leaching}

The leaching of $\mathrm{P}$ from the root zone of a cropped land area or from the surface soil material in any wastewater disposal project depends on the amount of water that moves across the boundary being considered and the $\mathrm{P}$ concentration in that volume. The amount of $P$ leached, in $\mathrm{kg} \mathrm{ha}^{-1} \mathrm{yr}^{-1}$ equals $0.1 \mathrm{WC}_{\mathrm{P}}$ where $\mathrm{W}$ is the ha-cm yr-1 of water that moves across the boundary, $C_{p}$ is the concentration of $\mathrm{P}$ in $\mathrm{mg} 1^{-1}$, and the constant 0.1 arises from the conversion to a $\mathrm{kg}$ basis. Thus, an appreciation of the amount and relative importance of the loss of $\mathrm{P}$ from a soil profile as a result of leaching can only be achieved by developing an understanding of the rate of infiltration and movement of water through a soil profile and the factors which control the soil solution $\mathrm{P}$ concentration at any particular depth in the profile.

Several mathematical models have been developed to describe the infiltration and movement of water through both undrained and drained soil profiles (Philip, 1957; Kirkham, 1958), and have been applied with varying degrees of success to the field situation (Rose, 1966). More recently, models have been constructed to deal specifically with the rate of solute (usually $\mathrm{NO}_{3}-\mathrm{N}$ ) move- ment in soils (Gardner, 1965; Biggar and Corey, 1969; Jury, 1975a,b). The model developed by Jury (1975a) was particularly successful in predicting solute travel times for tile-drained fields in several different localities under different practice (Jury, $1975 \mathrm{~b})$. The application of such models to predict the rate of $\mathrm{P}$ movement, however, is complicated by the interactions that take place between $P$ in the solid and solution phases of the soil profile.

The $\mathrm{P}$ concentration of the soil solution is controlled in the first instance by the reactions at soil mineral surfaces described in the previous section. The soil solution $\mathrm{P}$ concentration may also be modified by plant uptake of $P$. Such a reduction in the solution $\mathrm{P}$ concentration, however, probably operates through a reduction in the amount of sorbed $\mathrm{P}$ which in turn governs the $\mathrm{P}$ concentration in the soil solution. Consequently, it is reasonable to assume that sorption-desorption, and, in a few cases, precipitation-dissolution reactions are the ultimate control on soil solution $\mathrm{P}$ concentrations.

Values reported for the $\mathrm{P}$ concentration of the soil solution have ranged from 0.020 to $3.0 \mathrm{mg}^{-1}$ (Pierre and Parker, 1927; Barber et al., 1963; Russell, 1973; Sharpley et al., 1976), and depend on the position in the profile at which they are measured, and on the extent of previous $\mathrm{P}$ fertilization. Concentrations in surface horizons are generally higher than those in subsurface horizons. Barber $e t$ al. (1963) have reported an average dissolved inorganic $P$ concentration of $0.180 \mathrm{mg}^{-1}$ for the surface $15 \mathrm{~cm}$ of a group of 87 U.S. soils, whereas at 46 to $61 \mathrm{~cm}$ an average concentration of $0.089 \mathrm{mg}^{-1}$ was observed.

An illustration of the origin of this effect as a result of sorption-desorption reactions has been given by Ryden $e t$ al. (1973). When water is applied to the surface of a particular soil profile, a quasiequilibrium is established in the surface horizon. This will result in an increase or 
decrease in the solution P concentration, depending upon the saturation of $\mathrm{P}$ sorption sites, the presence of soluble fertilizerreaction products and the $P$ concentration in the water applied. In the case of rain water, which usually has $\mathrm{P}$ concentrations in the order of $0.01 \mathrm{mg} \mathrm{1}^{-1}$ (Gore, 1968; Taylor et al., 1971; White, 1972), release of $\mathrm{P}$ to solution will most probably occur. As the water percolates to $\mathrm{P}$ deficient subsurface horizons, resorption of $\mathrm{P}$ released in the surface horizon will occur resulting in a successive depletion of the solution $\mathrm{P}$ concentration. In wastewater disposal systems, however, the $\mathrm{P}$ concentration of the water applied to the soil surface may be sufficiently high that removal will occur even in the surface horizon.

The extent of the change in solution $P$ concentration at any depth in the profile will also depend on the time of contact between the percolating water and the soil mineral surfaces important in P sorption. The initial reaction between solution $\mathrm{P}$ and soils, however, is sufficiently rapid, as discussed previously, that even in systems where infiltration and percolation is rapid, some degree of change in solution $\mathrm{P}$ concentration at any depth is to be expected.

The concentration of $\mathrm{P}$ in leachates will also depend on the nature and amount of $\mathrm{P}$ sorbing components present in the soil profile, and the surface area exposed to percolating waters. Surface area is at a minimum in coarse textured soils, and will also be effectively reduced if channeling occurs or the profile is subject to cracking during periods when drying occurs.

The downward movement of $\mathrm{P}$ in croplands is usually a very slow process because volumes of percolating water are small and $\mathrm{P}$ concentrations are generally low. If 30 surface $\mathrm{cm}$ of water percolate past a given boundary in the soil profile and the concentration of $P$ in this water is $0.2 \mathrm{mg} 1^{-1}$, as might be the case in well-fertilized soils, the amount of $P$ moved is $0.60 \mathrm{~kg} \mathrm{ha}^{-1}$. The amounts of $\mathrm{P}$ absorbed by plant roots from soil depths beneath the zone of incorporation of added $\mathrm{P}$ more than balance this amount.
Thus, under usual fertilizer practices in agricultural lands the net leaching of $P$ is usually very small relative to the amount of $P$ applied.

In high-rate wastewater treatment systems, however, where large volumes of water move through the soil each year, the quantities of $\mathrm{P}$ that leach may be orders of magnitude higher than is usual for croplands. Under these conditions the factors limiting the leaching of $\mathrm{P}$ are the reactions which control the chemical mobility of $P$ in soils that were discussed in the previous section.

\section{Low-rate systems}

Low-rate systems are described by Bouwer and Chaney (1974) as those that receive wastewaters at rates of the same order of magnitude as the water requirement of crops or vegetation. The amounts are usually 60 to $150 \mathrm{~cm} \mathrm{yr}^{-1}$. At a rate of water application of $100 \mathrm{~cm} \mathrm{yr}^{-1}$ the amounts of $\mathrm{P}$ applied are 20, 50, 100, 200 and $400 \mathrm{~kg} \mathrm{ha}^{-1} \mathrm{yr}^{-1}$, respectively, for $P$ concentrations of $2,5,10,20$ and $40 \mathrm{mg} 1^{-1}$. If most wastewaters have concentrations of about $10 \mathrm{mg} 1^{-1}$ or less, the amounts added are of the same order of magnitude as fertilizer P applications to intensively farmed croplands. Consequently, another description of low-rate systems is those that receive $\mathrm{P}$ at rates comparable to fertilizer rates in which $P$ removal in harvested crops will be a significant sink for the added $P$. In low-rate systems, therefore, wastewaters not only add $\mathrm{P}$ at rates of the same order of magnitude as in agronomic practice, but crop growth is adequate for yields comparable to good agronomic management.

The fractional removal by a harvested crop of the $\mathrm{P}$ input from reclaimed water can be calculated from equation [3]:

$$
\mathrm{R}_{\mathrm{c}}=\frac{\mathrm{H}_{\mathrm{p}}}{0.10 \mathrm{WC}_{\mathrm{p}}}
$$

where $R_{c}$ is the fractional removal of the added $\mathrm{P}, \mathrm{H}_{\mathrm{P}}$ is the removal of $\mathrm{P}$ in the harvested crop in $\mathrm{kg} \mathrm{ha}^{-1} \mathrm{yr}^{-1}, \mathrm{~W}$ is the 
water intake in surface ha- $\mathrm{cm} \mathrm{ha}^{-1} \mathrm{yr}^{-1}$, $\mathrm{C}_{\mathrm{P}}$ is the $\mathrm{P}$ concentration in the wastewater in $\mathrm{mg}^{-1}$, and 0.10 is the proportionality factor to convert from $\mathrm{mg} 1^{-1}$ to $\mathrm{kg} \mathrm{ha}^{-1}\left(1.0 \mathrm{mg} 1^{-1}\right.$ equals $0.10 \mathrm{~kg}$ ha $\left.-\mathrm{cm}^{-1}\right)$.

Crop removal as a factor in predicting a loading rate for the use of wastewater on land is illustrated graphically in Fig. 3. The relationships show that crop removal can be a significant factor in the $\mathrm{P}$ balance when wastewater is applied at the low rate $\left(100 \mathrm{~cm} \mathrm{ha}^{-1} \mathrm{yr}^{-1}\right)$ assumed for the calculated curves in Fig. 3, and the solution $\mathrm{P}$ concentration is also relatively low. If a project is planned to grow forage crops in a long season so that 60 to $80 \mathrm{~kg} \mathrm{ha}^{-1} \mathrm{yr}^{-1}$ are removed, a $\mathrm{P}$ concentration of 10 to $20 \mathrm{mg} 1^{-1}$ can be used with crop removal as a significant sink for the added P. However, if the crop removal is less than about $40 \mathrm{~kg}$ $\mathrm{ha}^{-1} \mathrm{yr}^{-1}$ a desirable range for $\mathrm{P}$ concentration might be 5 to $10 \mathrm{mg} 1^{-1}$.

The retention of $\mathrm{P}$ near the place of its incorporation into soils is usually very high, i.e., the movement is very slow. Russell (1973), summarizing data from experimental plots at Rothamsted, reported that after $115 \mathrm{yr}$ of application of $34 \mathrm{~kg} \mathrm{P} \mathrm{ha-1} \mathrm{yr}^{-1}$ as superphosphate

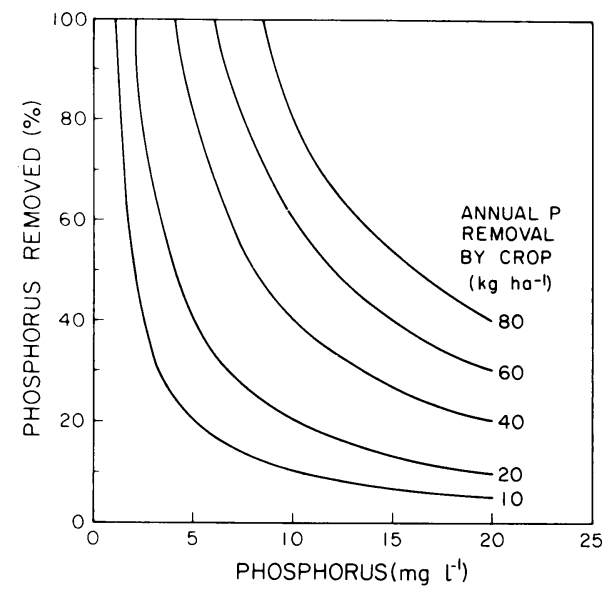

Fig. 3. Relationship among annual $P$ removal in harvested crops, $P$ removal as percent of input, and $\mathrm{P}$ concentration in wastewater applied at a rate of $100 \mathrm{~cm} \mathrm{ha}^{-1} \mathrm{yr}^{-1}$. Calculated from equation [3]. and $41 \mathrm{~kg} \mathrm{ha}^{-1} \mathrm{yr}^{-1}$ as manure there was no evidence of movement of $P$ beyond the $38 \mathrm{~cm}$ depth for the superphosphate treatment and only a suggestion that some $\mathrm{P}$ had moved beyond this depth for the manure treatment. When the superphosphate and manure treatments were combined there was clear evidence that some $\mathrm{P}$ had moved beyond the $38-\mathrm{cm}$ depth. Pratt et al. (1956) found that in an alkaline sandy-loam soil, fertilized at a rate of $64 \mathrm{~kg} \mathrm{P} \mathrm{ha}^{-1} \mathrm{yr}^{-1}$ for $28 \mathrm{yr}$, only a small amount of added $\mathrm{P}$ had moved into the 60 to $90-\mathrm{cm}$ depth, and there was no evidence tht $\mathrm{P}$ had moved into the 90 to $120-\mathrm{cm}$ depth. More than $60 \%$ of the added $\mathrm{P}$ had accumulated in the 0 to $15-\mathrm{cm}$ depth and more than $80 \%$ had accumulated in the 0 to $30-\mathrm{cm}$ depth.

The studies summarized above suggest that added $P$ has a tendency to remain close to the soil surface. It should be noted, however, that in the studies cited above $P$ was added as superphosphate rather than in solution as would be the case in wastewater treatment systems. Furthermore, the study sites were not subject to increased water movement through the soil profile that will inevitably occur at wastewater disposal sites, particularly at those receiving moderate rainfall. Hence, the importance of crop removal in maintaining relatively low levels of $P$ in the surface soil takes on an added significance in wastewater treatment systems. When the P loading of the soil is in excess of that which can be removed by a crop, the possibility of significant leaching of $P$ through the soil profile arises. Under such circumstances, the capability of the soil to remove $\mathrm{P}$ from the percolating water by sorption reactions becomes important.

For the reasons discussed previously, the greatest leaching of $P$ is to be expected from sandy and organic soils that have relatively low contents of $\mathrm{Fe}$ and $\mathrm{Al}$ hydrous oxides coupled with a low surface area. Spencer (1957) reported considerable downward movement of $\mathrm{P}$ during an 11-year period of $\mathrm{P}$ application to a siliceous sand that contained about $1 \%$ organic matter. Even though some P had leached to the 3-m depth, most of the 
added $\mathrm{P}$ was found in the 0 to $1.5-\mathrm{m}$ depth, which is within the rooting depth of many crops. Similar conclusions may be drawn from data reported by Neller (1947) and Ozanne (1963). Larson et al. (1958) also demonstrated that the movement of $\mathrm{P}$ in peat soils was relatively rapid, and inversely related to the content of $\mathrm{Al}$ and Fe hydrous oxides ("sesquioxides"), an observation in accord with the concept of $\mathrm{P}$ sorption discussed previously.

In the few studies directly related to the movement of $\mathrm{P}$ in wastewater treatment systems (Hook et al., 1973; Larson et al., 1974; Kardos and Hook, 1976), it has also been demonstrated that only small amounts of $\mathrm{P}$ are lost from the profile by leaching. Kardos and Hook (1976) found that the leaching of added $P$ beyond the 1.2-m depth during an 11-yr period was less than $3 \%$, whereas Larson et al. (1974) reported that less than 5\% of the $\mathrm{P}$ added during a $6 \mathrm{yr}$ had penetrated below the $30-\mathrm{cm}$ depth of a Sassafras sandy loam that had $\mathrm{pH}$ values of 5.8 to 6.8 .

Potential losses of $\mathrm{P}$ by leaching from field soils may be assessed by measurement of $P$ concentrations in waters flowing from subsurface drainage systems. Ryden et al. (1973) summarized the data for dissolved inorganic $P$ concentrations in tile-drain outflow and irrigation return flows from subsurface drainage. Mean values for individual studies ranged from 0.012 to $0.44 \mathrm{mg}^{1-1}$. More recently reported data (Baker et al., 1975; Calvert, 1975; Sharpley et al., 1976) tend to confirm these observations. Many concentrations measured in subsurface drainage are below those usually found in productive surface soils but the highest values were of the same order of magnitude. Solution $\mathrm{P}$ concentrations observed in tile-drain outflow also reflect depth of placement. Calvert (1975) reported that $\mathrm{P}$ concentrations averaged less than 0.02 $\mathrm{mg} 1^{-1}$ for tiles at a $1.1-\mathrm{m}$ depth, whereas the concentration for shallow lines (15 $\mathrm{cm})$ averaged $0.42 \mathrm{mg}^{-1}$. Such observations are in accord with the previous discussion of leaching.

Measurements of $\mathrm{P}$ loss in subsurface drainage suggest that 0.5 to $3 \%$ of the $P$ applied as fertilizer may be lost on an annual basis (Johnston et al., 1965; Bolton et al., 1970). Such losses are similar to measurements of the extent of $P$ movement in the wastewater treatment systems discussed above. This similarity strengthens the basis for comparison of low-rate wastewater treatment systems and normal cropland fertilizer practice.

The total transfer of $\mathrm{P}$ from land to streams in areas that are protected from excessive soil erosion, are usually less than $1.0 \mathrm{~kg} \mathrm{ha}^{-1} \mathrm{yr}^{-1}$ (Holt et al., 1970; Ryden et al., 1974; Gburek and Heald, 1974; Johnson et al., 1976; Sharpley and Syers, 1976). These small amounts are insignificant in terms of the efficiency of use of $\mathrm{P}$ by plants and they are small when expressed as percent of the $P$ sorbed by the soil. In terms of the quality of the drainage water, however, these small amounts of $\mathrm{P}$ can be significant when expressed as solution $\mathrm{P}$ concentrations in a particular drainage volume (Fig. 4). If $\mathrm{P}$ concentrations greater than $0.030 \mathrm{mg} 1^{-1}$ are conducive to algal blooms in lakes and streams (Sawyer, 1947; Holt et al., 1970), some streams which contain mainly drainage, both surface and subsurface, from land areas that have been cropped or subject to low-rate wastewater treatment, should have sufficient $P$ to support

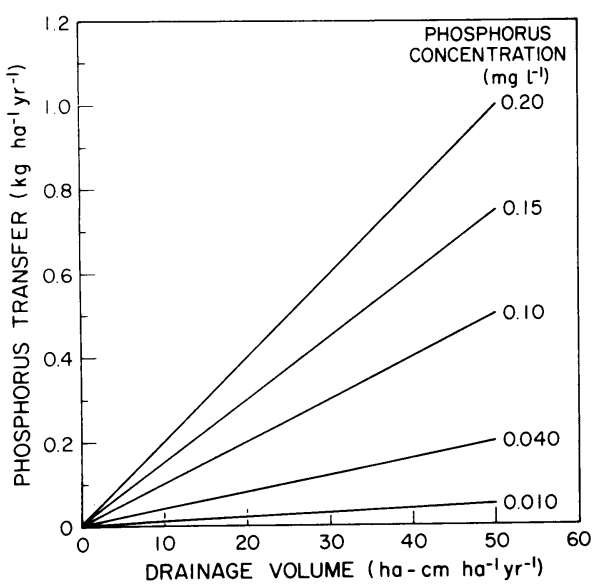

Fig. 4. Relationship among $P$ concentration in drainage water, drainage volume, and the transfer of $P$ from land to streams. 
algal blooms. Although the $\mathrm{P}$ concentration of drainage water from croplands may be reduced by dilution or resorption on sediments (Taylor and Kunishi, 1971; Kunishi et al., 1972), such inputs of $\mathrm{P}$ nevertheless represent an overall increase in the P loading of surface waters.

From the foregoing discussion, it is apparent that the essential features of a low-rate system should involve: 1) a forage crop that removes large amounts of $P, 2$ ) erosion prevention to eliminate surface runoff, and 3) a long pathway consisting of highly sorptive materials between the surface soil and the point of discharge of the water into surface or groundwaters, so that concentrations of $\mathrm{P}$ are reduced to desirable levels depending on the intended use of the water.

\section{High-rate systems}

High-rate systems are described as those in which the wastewater applied is much greater than that necessary for crop growth (Bouwer and Chaney, 1974). Amounts of water applied may be as high as several surface meters per week and agricultural utilization of the infiltration area is of no, or at least secondary, importance. Furthermore, unless the P concentration in high-rate systems is unusually low, the removal of $\mathrm{P}$ by harvested crops is also insignificant. If concentrations of $P$ are about $1 \mathrm{mg}^{-1}$ or less, the removal in harvested crops could be a significant sink for P (Fig. 5). At concentrations of 2.5 to $5 \mathrm{mg}^{-1}$ the amount of $\mathrm{P}$ removed by harvested crops will be of minor importance, whereas for concentrations in excess of $10 \mathrm{mg} 1^{-1}$ crop removal will be negligible at all but the lowest rates of water input (Fig. 5).

Greenberg and Thomas (1954) described a high-rate system on a Hanford sandy loam in which water containing 2 to 3 mg $1^{-1}$ was applied to infiltration basins at a rate of approximately 15 surface $\mathrm{cm}$ $\mathrm{dy}^{-1}\left(55\right.$ surface $\left.\mathrm{m} \mathrm{yr}^{-1}\right)$. During about $2 \mathrm{yr}$ of operation all of the $\mathrm{P}$ added was retained in the top $30 \mathrm{~cm}$ of the soil profile. The calcium and bicarbonate concentrations in the water were sufficiently high that the soil would have become alkaline, and $\mathrm{P}$ removed from solution may have been largely retained as $\mathrm{Ca}$ phosphates.

The most detailed report on $P$ removal in high-rate systems was that relating to the Flushing Meadows project (Bouwer and Chaney, 1974; Bouwer et al., 1974). The $\mathrm{P}$ concentration of the wastewater averaged $15 \mathrm{mg}^{-1}$ in 1969 but decreased to about $10 \mathrm{mg}^{1-1}$ for the $1970-72$ period. Phosphorus removal was increased with increase in travel distance. A travel distance of $9.2 \mathrm{~m}$ removed about $70 \%$ of the $P$ in 1969 . This was reduced to about $30 \%$ in 1970 , which resulted from a substantial increase in flow rate, but increased to $50 \%$ in 1972 . With a travel distance of $100 \mathrm{~m}$ the $\mathrm{P}$ removal was about $90 \%$. The effluent at this distance had a $\mathrm{P}$ concentration less than 1 to $3 \mathrm{mg} 1^{-1}$ in the 1971-72 period with greater reduction when an even longer travel distance was used. After 5 years of operation and addition of nearly $43,000 \mathrm{~kg} \mathrm{P} \mathrm{ha}^{-1}$, the $\mathrm{P}$ removal efficiency was rather stable. At this time, examination of the coarse gravelly soil at the treatment site suggested that a moderate proportion of $P$ removal from the wastewater had involved precipitation, probably as a calcium phosphate. The $\mathrm{P}$ removal in this project is entirely satisfactory for reuse of water for irrigating crops even at short travel dis-

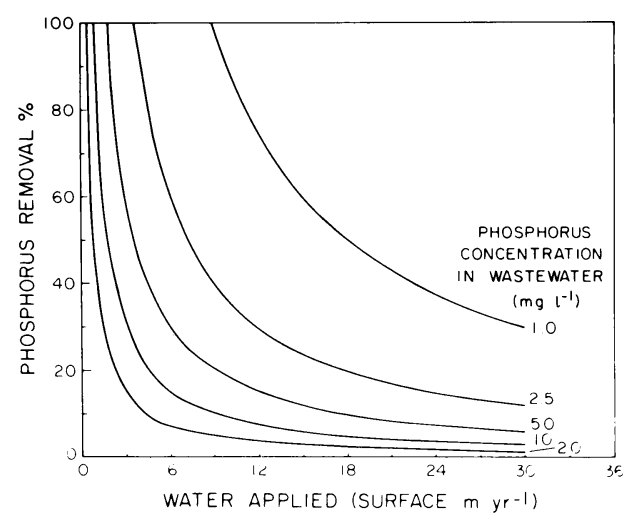

Fig. 5. Relationship between $P$ removal in harvested crops as a percentage of input, the amount of wastewater applied, and the concentration in the wastewater for an annual crop removal $\left(\mathrm{H}_{\mathrm{p}}\right)$ of $80 \mathrm{~kg} \mathrm{ha}^{-1}$. 
tances. The removal to the level (less than $0.03 \mathrm{mg} \mathrm{P} 1^{-1}$ ) where $P$ would limit biological production in recreational lakes, however, is uncertain in this high-rate system with this soil material.

High-rate systems naturally require coarse gravelly soils that can sustain a high infiltration rate and a high transmissivity from the point of infiltration to the point of discharge. Such soils are unlikely to have horizons with a high $\mathrm{P}$ sorption capacity, for the reasons discussed previously. What capacity there is in such soils will soon be saturated as a result of the high $\mathrm{P}$ loading and minimal crop removal. Any further removal of $P$ from solution will then depend on possibility of precipitation with other constituents in the wastewaters as a result of its contact with soil materials. Probably the most important potential precipitant is the Ca supply in the wastewater. If the $\mathrm{Ca}$ concentration in the wastewater is low, addition of $\mathrm{Ca}, \mathrm{Al}$, or $\mathrm{Fe}$, as is done in tertiary sewage treatment (Yee, 1966; Ames and Dean, 1970; Recht and Ghassemi, 1970; Lin, 1975; Stettler, 1975) may be considered if removal of $P$ is deemed important for the future use of the water.

One exception to the limitations discussed above may be found in the case of soils derived from tephra (volcanic ash deposits). Such soils frequently combine properties which could lead to a high infiltration rate and permeability, as well as a high $\mathrm{P}$ sorption capacity, particularly soils derived from andesitic tephra (Ryden and Syers, 1975b). Soils derived from tephra deposits, however, frequently have a limited geographic distribution, and their use for wastewater treatment will have similar limitations.

High-rate systems use a cycle of flooding and drying to maintain infiltration capacity and, in some cases, to control insect pests. Such a cycle may induce an oxidation-reduction cycle. This in turn may increase the $\mathrm{P}$ sorption capacity of the profile as a result of the conversion of $\mathrm{Fe}$ hydrous oxides to dominantly short-range order forms (Hsu, 1964; Syers and Williams, 1977). In most highrate systems, however, it would appear that the role of the soil in P removal is of secondary importance to the composition of the wastewater itself. This feature is shared with overland-flow systems.

\section{Overland-flow systems}

Overland-flow systems may be used in the case of soils with restricted permeability or when the suspended solids content of the wastewater is too high to permit a sufficiently rapid infiltration rate. As a result, most of the wastewater ruris off, and is collected at the toe of the slope. Treatment is obtained by the biological, chemical and physical interactions that occur as the water runs over the soil surface. The latter must be covered with grass, however, to protect the soil from erosion and to control the velocity at which water travels across the gently sloping surface.

Reduction in the $\mathrm{P}$ concentration of wastewater has been achieved using an overland flow treatment system. Such a reduction probably arises primarily from sorption reactions as the water containing $P$ contacts the surface soil. The usual reduction is 35 to $60 \%$ (Law et al., 1970; Kirby, 1971; Thomas et al., 1976). Thomas et al. (1976) found that the P concentration was reduced from $10 \mathrm{mg}$ total $\mathrm{P}^{-1}$ to about $5 \mathrm{mg}^{-1}$ in an overland-flow system. However, addition of aluminum sulfate at a concentration of $20 \mathrm{mg} \mathrm{Al} 1^{-1}$ to the wastewater reduced the $\mathrm{P}$ concentration of the treated water to about $1 \mathrm{mg} 1^{-1}$ for a $90 \%$ removal of the total $\mathrm{P}$ input. Such addition is analogous to a tertiary step in domestic sewage treatment. Removal of $P$ in such a treatment system probably arose from the precipitation of aluminum phosphates which were subsequently trapped at the soil surface during passage of the wastewater.

Data presented by Carlson et al. (1974) showed that phosphorus concentration decreased at a fairly uniform rate as wastewater ran over overland flow plots, to values 40 to $60 \%$ lower than those in the water applied. Analysis of water that percolated through the soil, however, suggested essentially complete $\mathrm{P}$ removal, 
whereas harvested grasses removed less than $10 \%$ of the $\mathrm{P}$ applied.

Optimum removal of $\mathrm{P}$ in overland flow systems will occur in cases where contact between water and soil surfaces is at a maximum. This can be achieved by increasing the roughness of the soil surface, increasing the vegetative cover, or by increasing the flow path.

\section{Wetland systems}

Although wetland systems have only recently been studied as a means of wastewater treatment (Spangler et al., 1976), the chemistry of $\mathrm{P}$ in similar environments has been studied for several years. Sufficient research has been completed on flooded rice culture that the behavior of $\mathrm{P}$ in flooded soils is fairly well understood. Also, recent work relating to the chemistry of $\mathrm{P}$ in lake sediments (Syers et al., 1973b) has furnished additional useful information.

When soils are flooded with a few feet of water, biological activities in the soil deplete the available oxygen, and the soil becomes anaerobic or, more specifically, anoxic (lack of oxygen). The water usually remains aerobic, and a transition zone between aerobic and anaerobic conditions develops in the immediate surface of the soil. The surface of this transition zone is aerobic and oxidized, whereas the bottom is anaerobic and reduced. The thickness of the oxidized part of this transition layer can vary from about 0.25 to $2.5 \mathrm{~cm}$ or more, depending on the rate of supply of oxygen to the surface of the soil and the rate of consumption of oxygen in the lower soil depths (Patrick and Mahapatra, 1968). In wetland situations where there is seasonal flooding followed by drying, such as in rice production, the soil goes through seasonal or yearly cycles of reduction and oxidation that result from cycles of anoxic and oxic conditions. Even in wetlands that are not seasonally flooded but are wet because of cyclical inputs of water, alternate periods of reduction and oxidation occur to some degree. Thus, one feature associated with all types of wetlands is the occurrence of reduced conditions or cycles of reduction and oxidation.

When soils and sediments become anoxic, most show an increase in soluble P (Patrick and Mahapatra, 1968; Ponnamperuma, 1972; Syers et al., 1973b; Patrick and Khalid, 1974; Khalid et al., 1977). This increase in soluble $P$ was found to be greatest with alkaline soils and with soils that have low iron contents, and to be lowest with acid soils with a high iron content (Ponnamperuma, 1972). Some acid soils with high iron contents show no increase or decrease in soluble $\mathrm{P}$ as reducing conditions develop. Patrick and Mahapatra (1968) stated that the possible mechanisms for release of soluble $\mathrm{P}$ principally involved the reduction of iron from the ferric to the ferrous state with a release of $P$ from ferric phosphates and the hydrolysis of iron and aluminum phosphates. In view of more recent research, the release of $\mathrm{P}$ could also be easily explained as arising from the reduction and partial dissolution of ferric hydrous oxides which in turn would release any adsorbed or absorbed phosphate associated with such components.

A wide variation has been reported in the ability of different sediments to sorb P (Carritt and Goodgal, 1954; Williams, et al., 1970; Laterell et al., 1971; Shukla et al., 1971). Some are capable of sorbing large additional amounts of $\mathrm{P}$, whereas others appear to be almost saturated (Williams et al., 1970, 1971). Williams et al. (1970) and Shukla et al . (1971) found that noncalcareous sediments sorbed more phosphorus than calcareous sediments. Shukla et al. (1971) reported that the oxalate treatment of lake sediments to remove iron and aluminum almost completely eliminated the ability of sediments to retain phosphorus. The amounts of iron removed were much greater than the amounts of aluminum removed by oxalate. They suggested that a gel complex of hydrated iron containing small amounts of aluminum oxide, silicon hydroxide, and organic matter was the major phosphorus-sorbing component in sediments under reduced conditions. A similar conclusion was drawn by Khalid et al. (1977), who reported a significant 
correlation between phosphorus sorbed under reduced conditions and the iron extracted by oxalate, also under reduced conditions. It was postulated that poorly crystalline and short-range order oxides and hydroxides of iron play a primary role in phosphorus retention by flooded soils and sediments.

These findings indicate that the chemical mobility of $P$ in sediments should be controlled by essentially the same reactions discussed previously for soils. A review of sediment $\mathrm{P}$ chemistry by Syers et al. (1973b) strongly suggests that this is indeed the case. The principle factor distinguishing dry-land soils from sediments, however, is the cyclical oxidationreduction to which the latter are subjected.

Although reduction generally gives rise to a release of $\mathrm{P}$ and a decrease in the amount of $\mathrm{P}$ that can be sorbed, reoxidation usually increases the potential $P$ sorption (Patrick and Mahapatra, 1968). This leads to lower $\mathrm{P}$ concentrations in the soil solution. Such behavior probably arises from the shift, during the reductionoxidation cycle, of crystalline and partially crystalline hydrous ferric oxides to shortrange order forms which have a considerably higher sorption capacity than their crystalline counterparts, as discussed in the section on $P$ sorption. The properties of sediments, in particular the generally high organic matter content, are also conducive to the formations of shortrange order components (Schwertmann, 1966). Consequently, the potential of marsh and wetlands for $P$ removal from wastewaters will be enhanced subsequent to complete or even partial reoxidation.

The problem of achieving adequate contact between sediments or soils and the wastewater represents a serious limitation to wetland wastewater treatment. Pomeroy et al. (1965) found evidence of significant exchange of phosphorus between sediments and water when the sediments were suspended in the water, but when they were separated the exchange was severely limited. Turnover times for the exchange of $\mathrm{P}$ between sediments and over-lying water in small lakes have been shown to range from 5.4 up to 40 days (Hayes et al., 1952). Where the sediments are not suspended, only a thin layer at the boundary between the water and the sediments is active in phosphorus retention. When wastewaters are added to wetlands, the sediments can play a significant part in removal of phosphorus from the water only if the water moves in and out of the sediments, or if wind or wave action keeps the sediments suspended. Running wastewater slowly over flooded soils in which plants are growing might be expected to remove phosphorus in a similar manner, and to about the same extent as found in overland flow systems. In both these systems, however, the capacity of soil and sediments to reduce phosphorus concentrations is not fully used.

After a 4-year study, Spangler et al. (1976) concluded that natural and artificial marshes did in fact have potential for wastewater treatment. In relation to phosphorus in a natural marsh, they found that (1) the marsh removed P during the summer and released it during other seasons, thus acting as a buffer; (2) harvesting of marsh vegetation had no potential for removing a large portion of the phosphorus input; and (3) passage of wastewater through $1900 \mathrm{~m}$ of the marsh reduced the $\mathrm{P}$ and total phosphorus concentrations by $13 \%$ or less. Some of this reduction was probably a result of dilution with other water. A mass balance using estimated water flows and concentrations, showed the same order of magnitude of phosphorus leaving the marsh as entering it. Consequently, the marsh acted only as a buffer for phosphorus concentration but was not effective in reducing the output.

In contrast to the natural marsh, however, artificial marshes removed $84 \%$ of the phosphorus input into greenhouse installations and $64 \%$ of the input into marshes constructed in the field (Spangler et al., 1976). They predicted that the removal in the field would be $80 \%$ under optimum conditions. Recommendations were for a system in which water would flow through, rather than over the soil in the artificial marsh, thus maximizing contact between the wastewater and components capable of removing $\mathrm{P}$. 


\section{MODELS}

\section{Background}

In a model that would be adequate for predicting the life of a wastewater treatment system, based on $\mathrm{P}$ retention in soils and sediments, many factors should be considered, including:

1. The rate of application of $P$.

2. The amounts of calcium, iron, and aluminum in the wastewater and the influence of these constituents on the sorption of $\mathrm{P}$ in the soil.

3. The removal of $P$ by plant roots if the model deals with time intervals of days or weeks, or annual removal of phosphorus in harvested crops if the time intervals are years or decades.

4. The travel distance and transit time of water flow.

5. The transit time for water to move through the system relative to the kinetics of phosphorus sorption in soils and sediments.

6. The rate of $P$ application to the land relative to the kinetics of phosphorus reactions with soils (rapid infiltration systems might move $\mathrm{P}$ through before the slow reactions have an effect on phosphorus concentration in the flowing water).

7. Capacities and kinetics of the sorption of $P$ in soils and sediments from land surface to the point of discharge into ground or surface waters.

Such a model would obviously be a three-dimensional model that would require information on water flow and phosphorus reactions that is usually not available and not easily obtained. Most water flow models and consequently proposed models for $\mathrm{P}$ removal from wastewaters, deal only with flow in one direction, although some work, such as that reported by Jury $(1975 a, b)$ deals with twodimensional water flow. Thus, the discussion here will deal with flow downward through soils and to a depth that can be sampled and studied at reasonable cost. This depth is perhaps 1.8 to $3 \mathrm{~m}$ for most situations but might be much deeper in cases of deep alluvial materials.

All models are based on a materials balance, i.e., the phosphorus that goes into a volume of soil must be retained in the solid phase, be removed by plants, or move through the soil volume in percolating water. This means that all models have a water flow component and a $\mathrm{P}$ reaction component, and, of course, in systems involving crops, plant removal is a third component for both water and P. Models can consist of simple bookkeeping for water and $\mathrm{P}$ balances or of mathematical equations of various degrees of sophistication.

\section{Limitations of models}

Although progress has been made during the past few years in the development of models of P movement in soils (Enfield and Bledsoe, 1973; Enfield, 1974; Enfield and Shew, 1975; Novak et al., 1975; Shah et al., 1975; Enfield et al., 1976; Hunter and Foster, 1976), there are a number of problems that need to be solved before mathematical models or any other predictive models can be used with any degree of accuracy. Large spatial and temporal variability in the hydraulic conductivity of field soils are known to occur and bring up the questions of how many and what kinds of samples or measurements are needed to characterize the water flow over an area for a given time. After the data are obtained, problems arise in averaging and interpreting such large variations (Nielsen et al., 1973; Jury et al., 1976).

There have been no studies of the numbers of samples needed to characterize the $\mathrm{P}$ sorption properties of a field to a given depth. Most sampling studies have dealt with problems of estimating the level of nutrients in the plow layer of soils. Recent studies of soil sampling for estimating the concentrations of soluble salts and nitrate in the unsaturated zone (to depths up to $6 \mathrm{~m}$ ) suggest that large numbers of samples are required and that adequate sampling of a field cannot be planned until some knowledge of the 
variability is obtained (Pratt et al., 1976; Rible et al., 1976). Similar information on $\mathrm{P}$ sorption is needed before models can be accurately applied to fields even if other limitations to the models are removed.

The composition of the wastewater, such as the concentrations of $\mathrm{Fe}, \mathrm{Al}$ and $\mathrm{Ca}$ may influence, to a greater or lesser extent, the $\mathrm{P}$ reactions in the soil. Reactions induced by wastewaters that acidify or alkalinize the soil will also have effects on $\mathrm{P}$ reactions. Until these effects become inputs into a reliable model the proper procedure would be to test each possible soil with the wastewater, or a reasonable simulation of the wastewater, being considered.

Perhaps the most serious limitation to all models is that to date the reaction of $\mathrm{P}$ with the soil cannot be predicted from measurements of simple soil properties that can be mapped in the field or measured quickly in the laboratory (Pratt et al., 1969; Enfield et al., 1976). Methods of characterizing soil that might correlate with $\mathrm{P}$ retention are likely to be more time-consuming than direct measurements of $\mathrm{P}$ sorption. If $\mathrm{P}$ sorption must be measured over a period of time to gain information on reaction kinetics, the question arises concerning the need for more than a very simple model, particularly considering spatial variability in water flow and $P$ retention properties of the fields on which the water will be applied.

In high-rate systems, the need for a model involving $\mathrm{P}$ sorption and crop removal is practically non-existent. Any high-rate system will require coarse gravelly or sandy soils, which usually have low sorptive capacities that are soon saturated. Consequently, the removal of $\mathrm{P}$ will, in most cases, depend more on the composition of the wastewater than on soil material itself as discussed before. Also, plant removal is usually too small to be significant. Thus, the need is for a model that considers the constituents in the wastewater and how these will react during flow through the soil and sediments as a function of distance of flow and rate of flow.

\section{Models for phosphorus movement through soils}

The mathematical model for onedimensional $\mathrm{P}$ movement in soils has been expressed in a number of ways. Enfield et al. (1976) expressed it as

$$
\frac{\delta C}{\delta t}=D \frac{\delta^{2} C}{\delta \bar{X}^{2}}-V^{\prime} \frac{\delta C}{\delta X}-\frac{\varrho}{\theta} \frac{\delta S}{\delta t}
$$

$$
\text { where } \begin{aligned}
\mathrm{C}= & \begin{array}{l}
\text { concentration of } \mathrm{P} \text { in solu- } \\
\text { tion }\left(\mathrm{mg} \mathrm{1}^{-1}\right)
\end{array} \\
\mathrm{D}= & \text { dispersion coefficient at } \\
& \text { velocity } \mathrm{V}^{\prime}\left(\mathrm{cm} \mathrm{hr}^{-1}\right) \\
\mathrm{t}= & \text { time }(\mathrm{hr}) \\
\mathrm{V}^{\prime}= & \text { average pore-water velocity } \\
& \left(\mathrm{cm} \mathrm{hr}^{-1}\right) \\
\mathrm{X}= & \text { distance from beginning of } \\
& \text { flow path }(\mathrm{cm}) \\
\pi= & \text { bulk density of soil }\left(\mathrm{g} \mathrm{cm}^{-3}\right) \\
\theta= & \text { volumetric water content in } \\
& \text { the soil } \\
\mathrm{S}= & \text { sorbed } \mathrm{P} \text { in solid phase } \\
& \left(\mu \mathrm{g} \mathrm{g}^{-1}\right) .
\end{aligned}
$$

The first two expressions in the equation deal with water flow and the third deals with the retention of $P$ by the soil, i.e., the kinetics of $\mathrm{P}$ reactions. Before this equation becomes a useful model the kinetics of $P$ reactions must be known.

Perhaps the most definitive evaluation of the kinetics of $\mathrm{P}$ sorption in relation to wastewater disposal was that of Enfield et al. (1976) who studied the reactions of $\mathrm{P}$ in 25 soils for a period of 2 to 18 weeks, and then used the data to test five kinetic models. Correlation coefficients between predicted values and experimental values averaged 0.81 to 0.88 , but these were the averages of values for individual soils. That is, coefficients for each kinetic model were calculated for and were unique to individual soils. Consequently, to use the models the $P$ reactions must be measured to supply the coefficients for the model for any individual soil material.

Enfield and Shew (1975) using two of the models tested by Enfield et al. (1976) found good agreement between the predicted movement of $P$ and values experimentally determined in small 
laboratory columns which were fed a solution containing $10 \mathrm{mg} \mathrm{P} 1^{-1}$. The first model was

$$
\frac{\delta S}{\delta t}=\alpha(\mathrm{KC}-\mathrm{S})
$$

where $\mathrm{C}$ is concentration of $\mathrm{P}$ in $\mathrm{mg} 1^{-1}$, $\mathrm{S}$ is concentration of sorbed $\mathrm{P}$ in $\mu \mathrm{g} \mathrm{P} \mathrm{g}{ }^{-1}$ of soil, $\mathrm{t}$ is time in hrs and $\alpha$ and $\mathrm{K}$ are constants that depend on the soil. The second model was

$$
\frac{\delta S}{\delta t}=\alpha C^{b} S^{d}
$$

where the symbols have the same meaning as before and $\alpha, b$ and $d$ are constants depending on the soil. Solutions to these equations were provided and constants calculated for two soils. Combinations of these with water flow data predicted $\mathrm{P}$ breakthrough curves for the two soils studied over a period of several days. Breakthrough curves indicated that the boundary between saturated and unsaturated soil (enriched versus non-enriched) was highly diffuse rather than abrupt.

Novak et al. (1975) developed a theoretical model for movement of $P$ in soils in which the $\mathrm{P}$ sorption factor of equation [4] was calculated from existing adsorptiondesorption models developed for chromatography and ion-exchange processes. This model predicts an abrupt boundary for breakthrough of soluble $P$ into any given layer of soil.

Harter and Foster (1976) developed an empirical model which describes the movement of $\mathrm{P}$ in soils. In this approach a soil sample is repeatedly treated with a solution of known $\mathrm{P}$ concentration and the sorbed $\mathrm{P}$ is determined. The relationship between $P$ sorbed and the volume of solution that has contacted the soil is then expressed as a polynomial adsorption equation

$$
\mathrm{Y}=\mathrm{A}+\mathrm{BX}+\mathrm{CX}^{2}+\mathrm{DX}^{3}
$$

in which $\mathrm{Y}=\mathrm{P}$ adsorbed and $\mathrm{X}$ is the amount of $\mathbf{P}$ added which is also readily converted to the volume of solution that has contacted the soil. From this relationship the $\mathrm{P}$ breakthrough curves or the $\mathrm{P}$ leaching front can be plotted against depth or volume of wastewater added.
The model is simple and might be adequate for most purposes, but there are no data available showing the effectiveness of the approach in predicting field data.

Shah et al. (1975) developed a materials balance mathematical model which agreed well with field data obtained from the barriered landscape water renovation system used to treat liquid swine manure. In this model the sorption-kinetic equation was based on the use of the Langmuir equation.

\section{Empirical model for low-rate system}

One of the major problems with the models described in the previous section is that all require fairly detailed laboratory work over a considerable period to obtain parameters relating to the extent and rate of $\mathrm{P}$ sorption by each soil. This has been necessary because, until recently, there has been no generally applicable $P$ sorption model that could be used as the basis for a simple test of the potential of a soil for $\mathrm{P}$ removal at a wastewater treatment site. This was particularly true with respect to the slow reactions of $P$ which are likely to be of considerable importance in determining the longevity of a treatment site with respect to $P$ removal.

In this simple model the $\mathrm{P}$ added minus the $\mathrm{P}$ removed in harvested crops is assumed to react progressively with successive depth increments in the soil. The first depth increment becomes "saturated" before P moves to the next depth increment and the boundary between the P-enriched soil and the non-enriched soil is assumed to be rather abrupt as in the theoretical model of Novak et al. (1975). The term "saturated" is defined for the purposes of this model as the soil in which enrichment with $\mathrm{P}$ has been sufficient that movement of $P$ with percolating water is significantly above the background for the original soil material. This model also considers water movement to be so unimportant relative to $P$ reactions that it can be disregarded. Consequently, there will be sufficient time for slow $P$ reactions to have a large 
impact, and the $\mathrm{P}$ sorption capacities for the depth increments will include the slow reactions.

This model, expressed mathematically, is

$$
\mathrm{T}=\frac{\mathrm{Sp}}{\mathrm{Ip}-\mathrm{Hp}}
$$

where $T$ is time in years for the $P$ front to reach a given depth in the soil, $S_{p}$ is the sorption capacity of the volume of soil above that depth expressed in $\mathrm{kg} \mathrm{ha}^{-1}$, $\mathrm{I}_{\mathrm{p}}$ is the input of $\mathrm{P}$ in $\mathrm{kg} \mathrm{ha}^{-1} \mathrm{yr}^{-1}$ and $\mathrm{H}_{\mathrm{p}}$ is the $\mathrm{P}$ removed in harvested crops in $\mathrm{kg} \mathrm{ha}^{-1} \mathrm{yr}^{-1}$. An example of the application of this model to predict the longevity of a treatment site using reasonable but hypothetical values for the parameters in equation [8], is illustrated in Fig. 6.

Values required for the parameters in equation [8] are relatively easily obtained. The values of $\mathrm{I}_{\mathrm{p}}$ and $\mathrm{H}_{\mathrm{p}}$ can be determined with reasonable accuracy by well established techniques. Furthermore, there is also a reasonably extensive data base from which values of $\mathrm{H}_{\mathrm{p}}$ can be predicted. The measurement of the equilibrium sorption capacity term $\left(S_{p}\right)$, however, is less well established. Recently reported work (Barrow and Shaw, 1974; Holford et al., 1974; Holford and Mattingly, 1975a; Ryden and Syers, 1977b; Ryden et al., 1977a), however, has suggested a relatively simple approach to determining the

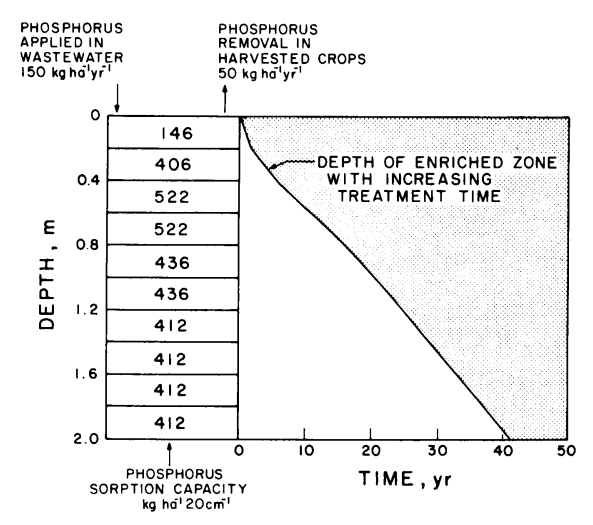

Fig. 6. Illustration of a simple $P$ balancereaction model for low-rate wastewater treatment systems. Calculated from equation [8]. parameters relating to the rate and extent of $\mathrm{P}$ sorption.

It should be noted that the term $\mathrm{S}_{\mathrm{p}}$ in equation [8] is not the overall sorption capacity of the soil material, but the sorption capacity at a solution $\mathrm{P}$ concentration equivalent to the average value of that found in the wastewater applied. This term is difficult to measure on a routine and detailed basis as would be required for the evaluation of the potential of various sites for wastewater treatment. Using the interpretation of $\mathrm{P}$ sorption isotherms suggested by Ryden and Syers (1977b), an estimate of the overall equilibrium sorption maximum of a soil is not difficult to obtain. From this value, an estimate of $S_{p}$ for any solution $P$ concentration may be obtained as described below.

As was discussed in the Section on $P$ sorption, the sorption of $\mathrm{P}$ by contrasting subsoils and topsoils, can be described by essentially the same three-equation Langmuir sorption model (Ryden et al., 1977a). This finding makes it possible to construct a generalized isotherm (Fig. 7) for equilibrium $\mathrm{P}$ sorption by different

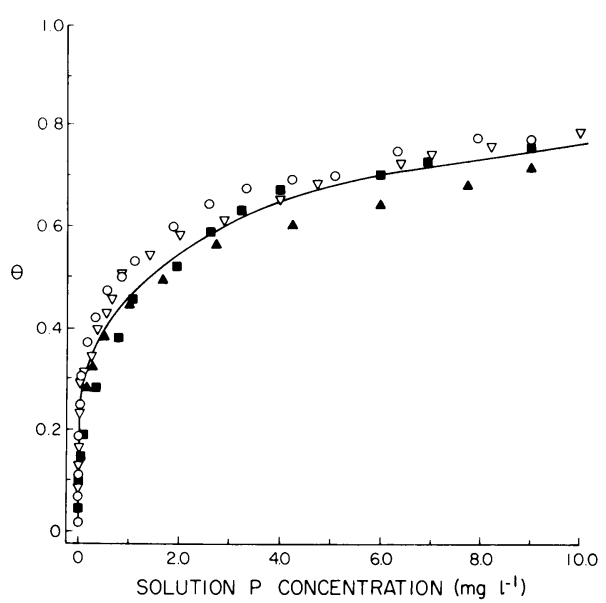

Fig. 7. Rationalized equilibrium isotherm for $\mathrm{P}$ sorption by four contrasting soils. $\theta=$ $x b^{-1}$ where $x$ is the amount of $P$ sorbed at any particular solution $P$ concentration and $b$ is the equilibrium sorption maximum. $\mathrm{O}=$ Okaihau soil; $\boldsymbol{\nabla}=$ Egmont soil; $\boldsymbol{\Delta}=$ Waikakahi soil; $\boldsymbol{\square}=$ Porirua soil. Data from Ryden et al. (1977a). 
soils when the amount of $\mathrm{P}$ sorbed at equilibrium is expressed as a fraction $(\theta)$ of the overall equilibrium sorption maximum. The fact that essentially the same isotherm was obtained for each of the four soils used to obtain data in Fig. 7, reflects the fact that only the sorption maximum varies between soils and not the nature of sorption itself (Ryden et al., 1977a).

To estimate the amount of $P$ sorbed at any particular solution $P$ concentration, e.g., the average for the wastewater under consideration, all that is required is an estimate of the overall equilibrium $P$ sorption maximum. This may be achieved by determining the equilibrium $\mathrm{P}$ sorption level for any $\mathrm{P}$ addition to the soil which results in an equilibrium solution $P$ concentration of $10 \mathrm{mg} \mathrm{P} 1^{-1}$ or less, using the method described by Ryden and Syers (1975c). In this method a quantity of soil is shaken with a solution containing added $\mathrm{P}$ at a relatively wide solution to soil ratio. The solution $\mathrm{P}$ concentration at several times ( $t$ ) greater than 80 hours after addition of $P$ to the soil suspension, is determined and graphed against $1 / t$. The resulting linear relationship is extrapolated to $1 / \mathrm{t}=0$, i.e., infinite time, and the solution $P$ concentration obtained is used as the estimate for the equilibrium solution $P$ concentration for the $\mathrm{P}$ addition made. From this concentration and the amount of added $P$, the amount of $\mathrm{P}$ sorbed at equilibrium may be calculated. This quantity of sorbed $\mathrm{P}$ must be adjusted, however, to the effective equilibrium sorption level by adding to it the amount of sorbed $\mathrm{P}$ initially present in the soil, i.e., the amount of native sorbed $\mathrm{P}$ (Holford et al., 1974; Ryden et al., 1977a). The amount of native sorbed $\mathrm{P}$ may be measured as that removed in a $0.1 \mathrm{M} \mathrm{NaOH}$ extraction of the soil (Ryden et al., 1977b). The equilibrium sorption maximum (b) can then be calculated from equation [9]

$$
\mathrm{b}=\mathrm{x} / \theta
$$

in which $\mathrm{x}$ is the experimentally determined equilibrium sorption level for the single $P$ addition used, and $\theta$ is the fractional sorption saturation obtained from
Fig. 7 for the experimentally observed equilibrium solution $\mathrm{P}$ concentration. From the calculated $b$ value, the amount of $\mathrm{P}$ sorbed at any equilibrium $\mathrm{P}$ concentration may be calculated by using the appropriate $\theta$ value obtained from Fig. 7 .

The potential facility of the generalized $P$ sorption isotherm (Fig. 7) is illustrated by the interpretation of $\mathrm{P}$ sorption data obtained for a Ramona sandy-loam soil (Table 2), a soil which was not used in the original development of this model (Ryden and Syers, 1977b). The equilibrium $\mathrm{P}$ sorption levels $(\mathrm{x})$ were determined as described above from the estimated equilibrium solution $P$ concentrations observed after making various additions of $\mathrm{P}$ to suspensions of the soil. The sorption maximum (b), calculated from equation [9], was essentially the same irrespective of the level of $\mathrm{P}$ addition used. As, by definition, $\mathrm{b}$ is a constant, this observation demonstrated that $\mathrm{P}$ sorption by Ramona soil (Table 2) was described by essentially the same isotherm as that in Fig. 7 which was obtained independently using four completely different soils. Consequently, if Ramona soil was to be used to remove $P$ from wastewater with an average $P$ concentration of $5 \mathrm{mg} 1^{-1}$, the equilibrium sorption level $(x)$ at this solution $\mathrm{P}$ concentration can be calculated as $114 \mu \mathrm{g} \mathrm{P} \mathrm{g}^{-1}$ based on a $\theta$ value of 0.68 (Fig. 7) and the equilibrium sorption maximum of $168 \mu \mathrm{g} \mathrm{P} \mathrm{g}^{-1}$ obtained using a $\mathrm{P}$ addition of $120 \mu \mathrm{g} \mathrm{P} \mathrm{g}^{-1}$ (Table 2). A similar equilibrium sorption level at 5 $\mathrm{mg} 1^{-1}$ would have been obtained irrespective of the data line from Table 2 used in the calculation. With respect to the ability of the soil to remove $\mathrm{P}$ added to it in wastewater, the equilibrium sorption level must be adjusted by deducting the amount of native sorbed $P$ initially present (29 $\mathrm{ug} \mathrm{g}^{-1}$; Table 2) to give an effective equilibrium sorption level of $85 \mu \mathrm{g} \mathrm{P} \mathrm{g}{ }^{-1}$. From this value and a knowledge of the field bulk density of the soil in question, the $\mathrm{P}$ sorption capacity for the soil depth of interest $\left(S_{p}\right.$ in equation 8$)$ can be calculated and expressed in $\mathrm{kg} \mathrm{Pha}^{-1}$.

The use of a wide solution to soil ratio facilitates the measurement of the equilibrium sorption parameters required for 
this model. A relatively wide ratio is valid in the case of equilibrium measurements as it has been shown that at equilibrium the amount of $\mathrm{P}$ sorbed at any solution $\mathrm{P}$ concentration is essentially independent of the solution to soil ratio used (Hope and Syers, 1976). Consequently, estimates of the sorption maximum can be made in the laboratory using simple shaking procedures, and from such measurements the sorption capacity at any particular solution $P$ concentration relevant to a wastewater treatment system can be determined.

The uncertainties in the $\mathrm{P}$ balancereaction model described by equation [8] are the assumed abrupt boundary between enriched and non-enriched soil and the assumption that water movement is slow enough to allow complete sorption equilibrium. There is ample evidence from fields that have received large amounts of $\mathbf{P}$ as fertilizer or wastes that soluble $\mathbf{P}$ decreases gradually as a function of depth with a diffuse rather than an abrupt boundary between the enriched and non-enriched soil horizons (Pratt et al., 1956; Spencer, 1957; Taylor and Kunishi, 1974; Kardos and Hook, 1976). The extent of water movement in a waste water treatment system will vary and depend upon several factors. These include application rate, textural class of the soil used, rate of infiltration and percolation, and the amount of water lost by evapotranspiration. Nevertheless, considering these uncertainties, the model may be useful as a preliminary estimate of the longevity of a particular disposal site. Furthermore, this model is also amenable to a relatively simple measurement of $P$ sorption capacity which should have direct relevance to the field situation. This type of model is implied in the rate classes proposed by Schneider and Erickson (1972) for P sorption measurements in soils as a limitation for the use of the soil for municipal wastewaters. Their limitation classes ranged from very high to very low, respectively, as the $\mathrm{P}$ sorption increased from less than 1,120 to more than $2,240 \mathrm{~kg} \mathrm{ha}^{-1}$ in $0.9 \mathrm{~m}$ of soil.

In wastewater treatment systems where appreciable water movement is expected to occur, application of the $\mathrm{P}$ balancereaction model may still be feasible if the kinetics of $\mathrm{P}$ reactions are taken into account. The work of Barrow and Shaw (1976) not only suggests a useful approach to this end, but also allows the model to be kept, on a generalized basis.

In order to maximize $P$ sorption potential, it is necessary to divide the proposed treatment area into sections over which wastewater is applied for a given period of time. An estimate of the sorption capacity of a weighted average mix of the whole profile at a given breakthrough solution $\mathrm{P}$ concentration at the base of the profile is then determined using a sorption time equal to the expected travel time of water through the profile. This breakthrough concentration may be selected on an arbitrary basis representing

TABLE 2.

EQUILIBRIUM P SORPTION DATA FOR A RAMONA SANDY-LOAM SOIL AND RELATED DATA CALCULATED FROM THE GENERALIZED P SORPTION ISOTHERM IN FIGURE 7

\begin{tabular}{|c|c|c|c|c|}
\hline Padded & $\begin{array}{l}\text { Equilibrium P } \\
\text { Concentration }\end{array}$ & $\begin{array}{l}\text { Equilibrium P } \\
\text { Sorption }(\mathbf{x})^{+}\end{array}$ & $\theta \mathrm{T}$ & $\begin{array}{c}\text { Calculated } \\
\text { sorption } \\
\text { maximum (b) } \$\end{array}$ \\
\hline$\mu g g^{-1}$ & $m g 1^{-1}$ & $\mu g g^{-1}$ & & $\mu g g^{-1}$ \\
\hline 5 & 0.033 & 32.0 & 0.18 & 178 \\
\hline 10 & 0.080 & 35.0 & 0.21 & 167 \\
\hline 20 & 0.157 & 41.2 & 0.26 & 159 \\
\hline 40 & 0.285 & 54.7 & 0.32 & 171 \\
\hline 80 & 0.655 & 76.3 & 0.44 & 173 \\
\hline 120 & 1.33 & 82.5 & 0.49 & 168 \\
\hline 500 & 8.00 & 129 & 0.75 & 172 \\
\hline
\end{tabular}

\footnotetext{
* Values include $29 \mu \mathrm{g} \mathrm{P} \mathrm{g}^{-1}$ native sorbed P.

I Obtained from the generalized isotherm (Fig. 7).

Calculated from equation (9).
} 
a certain percentage removal of $P$ from the wastewater being treated, or may be dictated by local operating codes. The sorption capacity value may be estimated from a three or four point sorption isotherm determined using a very narrow solution to soil ratio (1:1 or less) so as to bracket the pre-set breakthrough concentration. This would be most reliably achieved using incremental additions of $P$ to the soil (Harter and Foster, 1976) but a value based on several individual but different additions of $\mathrm{P}$ (Sawheny, 1977) may be equally satisfactory. The sorption capacity value obtained will provide an estimate of the initial longevity of one section of the treatment area. Wastewater would then be applied to other sections of the site in turn, returning to the original section only after a given time which would be a sum of the longevity of each section to the stipulated breakthrough $\mathrm{P}$ concentration.

During this time period, the $\mathrm{P}$ sorption potential of the soil at the original section of the treatment area will have regenerated to a certain degree. The regeneration of sorption potential should be described by the generalized kinetic equation [1] given by Barrow and Shaw (1974) and discussed previously. That is, during the rest period a certain proportion of the overall amount of $P$ sorbed shifts from the more-physically sorbed form (compartment B) to the chemi-sorbed form (compartment $\mathrm{C}$ ), thus increasing the number of surface sorption sites by that amount before the breakthrough P concentration is reached again. The additional extent of $\mathrm{P}$ sorption, therefore, can be calculated from the relationship in Fig. 2 describing the proportional shift of $\mathrm{P}$ from compartment $B$ to compartment $C$. The proportion of the original sorption capacity at the breakthrough $\mathrm{P}$ concentration that is regenerated during a particular time interval is equal to the change in the value of $1-\alpha$ during that time interval. Hence, the extent of additional $P$ sorption $\left(\mathrm{S}_{2}\right)$ that is possible as a result of sorption site regeneration may be expressed as:

$$
\mathrm{S}_{2}=\mathrm{S}_{1}(1-\alpha) \mid \begin{aligned}
& \mathrm{t}_{1}^{0} \\
& \mathrm{t}_{1}^{0}
\end{aligned}
$$

where $S_{1}$ is the $P$ removed at breakthrough during the initial application. Zero time $\left(t_{o}\right)$ is taken as the end of the first application and $t_{1}$ is the time elapsed before the second application. Consequently, at the $n$th application the additional $P$ sorption $\left(S_{n}\right)$ is given by:

$$
\begin{aligned}
& \mathrm{S}_{\mathrm{n}}=\left.\mathrm{S}_{1}(1-\alpha)\right|_{\mathrm{t}_{\mathrm{n}}} ^{\mathrm{t}_{\mathrm{n}-1}}+ \\
& \mathrm{S}_{2}(1-\alpha) \mid \begin{array}{l}
\mathrm{t}_{\mathrm{n}-2} \\
\mathrm{t}_{\mathrm{n}-1}
\end{array} \ldots+ \\
& \left.\mathrm{S}_{\mathrm{n}-1}(1-\alpha)\right|_{\mathrm{t}_{1}^{2}} ^{\mathrm{t}_{2}}
\end{aligned}
$$

and the total amount of $\mathrm{P}$ sorbed is $\left(\mathrm{S}_{1}+\right.$ $\mathrm{S}_{2}+\ldots \mathrm{S}_{\mathrm{n}}$ ).

This approach considers that the $P$ sorbed during any application period occupies a distinct "parcel" of sorption sites, each parcel having the ability to regenerate itself with increasing time after that parcel was initially saturated. The sum of the regenerative capacity of each parcel of sites over a particular rest period

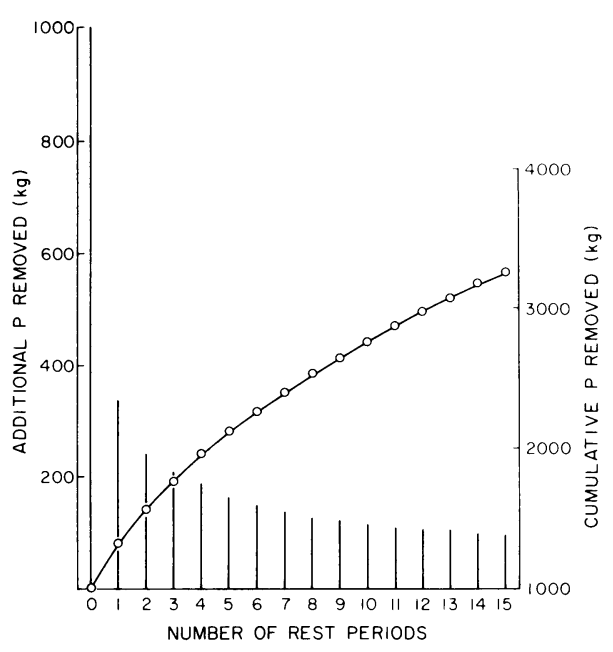

Fig. 8. Additional $P$ removal and cumulative $P$ removal after successive rest periods subsequent to an initial $P$ sorption of $1000 \mathrm{~kg}$ by a hypothetical soil profile in one section of a wastewater disposal area divided into ten sections to which wastewater is applied sequentially. Relationships derived from Fig. 2 and equation [11]. 
is the cumulative regeneration of $\mathrm{P}$ sorption sites at that time after the initial application.

An illustration of this interpretation is given in Fig. 8. In the calculation of the relationship in Fig. 8, it was assumed that the proposed disposal area was divided into ten sections, and that the profile depth of one section had an initial sorption capacity to the breakthrough $\mathrm{P}$ concentration of $1,000 \mathrm{~kg} P$ per unit area. If this amount of $\mathrm{P}$ is applied over 7 days, the rest period between applications to a particular section is 63 days. A rest period of this length results in a change in the value of $1-\alpha$ of 0.33 for a temperature of $18^{\circ} \mathrm{C}$ (Fig. 2). Hence the additional sorption capacity during the second application period $\left(\mathrm{S}_{2}\right)$ calculated from equation [10] is $330 \mathrm{~kg} \mathrm{P}$.

As can be seen from Fig. 8, the value of $S_{n}$ decreases with time, dramatically at first, but then more slowly, and tends to approach a relatively constant value. Such a decrease in the additional amount of $\mathrm{P}$ removed after each rest period causes some practical problems in terms of selecting an operational wastewater application rate for satisfactory $\mathrm{P}$ removal. This problem could be overcome by averaging the additional amounts of $\mathrm{P}$ which can be removed after the first rest period for $\mathrm{n}$ rest periods, where $\mathrm{n}$ is the number of rest periods giving an average additional removal value equal to the minimum operational application rate. In the case of the worked example for fifteen rest periods the $\mathrm{P}$ application rate would be $155 \mathrm{~kg}$ P.

This model based on the kinetic relationships of Barrow and Shaw (1974) is also flexible in that after the initial application, rest times can be varied so that any disposal site can be used to its optimum potential in relation to the expected amount of $\mathrm{P}$ to be applied, the $\mathrm{P}$ sorption capacity of the profile, and the size of the area available. The principal limitation of the approach, however, is the assumption that the approach to the $\mathrm{P}$ sorption capacity at the desired breakthrough concentration will be the same at all depths in the profile. This will obviously not be the case for the reasons outlined in section 3 relating to the leaching of $\mathrm{P}$ through soil profiles. Consequently, the initial sorption $S_{1}$, as well as the extent of additional sorption, will be underestimated. It is possible that a more reliable estimate of $S_{1}$ may be obtained if it is considered that a certain proportion of the profile depth (possibly $80 \%)$ is involved in the removal of a major proportion of the $P$ applied. The remaining $20 \%$ may be considered as a "scrubbing" depth to decrease the effluent concentration to a value equal to or lower than the imposed break through value. The value $S_{1}$ could then be defined and determined as the amount of $P$ sorbed by a weighted average of the upper portion of the profile at the average solution $\mathrm{P}$ concentration of the effluent during a time equal to the average travel time of the effluent through the profile. The limitation discussed above, however, does not affect the estimation of the rate of sorption site regeneration, as this is independent of the amount of $\mathrm{P}$ present (Barrow and Shaw, 1974).

A further refinement to this approach could be made to allow for the effects of temperature on the regeneration of sorption capacity. The kinetic model, upon which the approach discussed above is based, implies an appreciable increase in the rate of regeneration of sorption capacity with an increase in temperature (equation [2]; Fig. 2).

The benefit and convenience of the two experimental approaches described above to the evaluation of the potential and longevity of a particular site for $P$ removal from wastewaters, lies in the fact that they are based on $\mathrm{P}$ sorption models which have been shown to be independent of soil type. Furthermore, the kinetic model of Barrow and Shaw (1974, Fig. 2) was also shown to be virtually independent of water content and the amount of $P$ added. Although the approaches outlined in this section require further development, the concepts upon which they are based suggest considerable versatility and a wide applicability to systems where sorption is expected to be the dominant removal mechanism. Furthermore, with some conceptual modifications to allow 
for the differences between high- and low-rate systems, the model outlined in Fig. 8 could be adapted to predict $P$ removal in high-rate systems. It is this type of model, involving experimental determinations that can be made in relatively short time periods and on a routine basis, that is required for the evaluation of sites suitable for wastewater disposal. 


\section{LITERATURE CITED}

AGRICULTURAL WASTE MANAGEMENT FIELD MANUAL.

1975. U. S. Dept. Agriculture, Soil Conservation Service.

AMES, JR., L. L.

1970. A mobile pilot plant for the removal of soluble phosphorus from wastewaters by absorption on alumina columns. Water Pollut. Cont. Research Series 17010 EER 06/70. pp. 31. U. S. Dept. Interior, Fed. Water Pollut. Cont. Admin. Cincinnati, Ohio.

AMES, JR., L. L., AND R. B. DEAN.

1970. Phosphorus removal from effluents in alumina columns. J. Water Pollut. Control Fed. 42:R161-72. BACHE, B. W.

1963. Aluminum and iron phosphate studies relating to soils. I. Solution and hydrolysis of variscite and strengite. J. Soil Sci. 14:113-23.

1964. Aluminum and iron phosphate studies relating to soils. II. Reactions between phosphate and hydrous oxides. J. Soil Sci. 15:110-16.

BACHE, B. W., AND E. G. WILLIAMS.

1971. A phosphate sorption index for soils. J. Soil Sci. 22:289-301.

BAKER, D. E., AND L. CHESNIN.

1975. Chemical monitoring of soils for environmental quality and animal and human health. Adv. Agron. 27:305-74.

BAKER, J. L., K. L. CAMPBELL, H. P. JOHNSON, ANDJ. J. HANWAY.

1975. Nitrate, phosphorus, and sulfate in subsurface drainage water. J. Environ. Quality 4:406-12.

BARBER, S. A., J. M. WALKER, AND E. M. VASEY.

1963. Principles of ion movement through the soil to the plant root. Trans. Joint-Meeting Comm. IV and V, Intern. Soc. Soil Sci., New Zealand, 1962. 121-4.

BARROW, N. J., AND T. C. SHAW.

1974. Factors affecting the long-term effectiveness of phosphate and molybdate fertilizers. Comm. Soil Sci. Plant Anal. 5:355-64

BIGGAR, J. W., AND R. B. COREY.

1969. Agricultural drainage and eutrophication. In Eutrophication: Causes, Consequences, Correctives. p. 404-45. National Academy of Sciences, Washington, D.C.

BINGHAM, F. T

1966. Phosphorus. In Diagnostic Criteria for Plants and Soils. (H. D. Chapman, ed.). Univ. of Calif., Division of Agri. Sciences.

BLANCHAR, R. W., AND L. R. HOSSNER.

1967. Hydrolysis and sorption of ortho-, pyro-, trypoly-, and trimetaphosphate in 32 mid-western soils. Soil Sci. Soc. Amer. Proc. 33:622-5.

BLANCHAR, R. W., AND D. C. RIEGO.

1976. Tripolyphosphate and pyrophosphate hydrolysis in sediments. Soil Sci. Soc. Amer. J. 40:225-9.

BOLTON, E. F., J. W. AYLESWORTH, AND F. R. HORE.

1970. Nutrient losses through tile drains under three cropping systems and two fertility levels on Brookston clay soil. Can J. Soil Sci. 50:275-9.

BOUWER, H., AND R. L. CHANEY.

1974. Land treatment of wastewater. Adv. Agron. 26:133-76.

BOUWER, H., J. C. LANCE, AND M. S. RIGGS.

1974. High rate land treatment. II. Water quality and economic aspects of the Flushing Meadows project. J. Water Pollut. Cont. Fed. 46:844-59.

BROWN, G., AND A. C. D. NEWMAN.

1973. The reactions of soluble aluminum with montmorillonite. J. Soil Sci. 24: 339-54.

BRUNAUER, S., E. E. COPELAND, AND D. L. KANTRO.

1966. The Langmuir and BET theories. In The gas-solid interface, Vol.1, E. A. Flood (ed.). p. 77-85. Marcel Dekker, New York.

CALVERT, D. V.

1975. Nitrate, phosphate and potassium movement into drainage lines under three soil management systems. J. Environ. Quality 4:183-6.

CARLSON, C. A., P. G. HUNT, AND T. B. DELANEY, JR.

1974. Overland flow treatment of wastewater. U.S. Army Engineering Waterways Experiment Station. Vicksburg, Miss. Misc. Paper Y-74-3.

CARRITT, D. E., AND S. GOODGAL.

1954. Sorption reactions and some ecological implications. Deep Sea Research 1:224-43.

CHAKRAVARTI, S. N., AND C. TALIBUDEEN.

1962. Phosphate equilibria in acid soils. J. Soil Sci. 13:231-40. 
CHEN, Y. R., J. N. BUTLER, AND W. STUMM.

1973a. Adsorption of phosphate on alumina and kaolinite from dilute aqueous solution. J. Coll. Interface Sci. 43:421-36.

1973b. Kinetic study of phosphate reaction with aluminum oxide and kaolinite. Environ. Sci. Tech. 7:327-32.

CLARK, J. S., AND M. PEECH.

1955. Solubility criteria for the existence of calcium and aluminum phosphates in soils. Soil Sci. Soc. Amer. Proc. 19:171-4.

1960. Influence of neutral salts on the phosphate ion concentration in the soil solution. Soil Sci. Soc. Amer. Proc. 24:346-8.

COLE, C. V., AND M. L. JACKSON

1950a. Colloidal dihydroxy dihydrogen phosphates of aluminum and iron established by electron and X-ray diffraction. J. Phys. Colloid Chem. 54:128-42.

1950b. Solubility equilibrium constant of dihydroxy aluminium dihydrogen phosphate relating to a mechanism of phosphate fixation in soils. Soil Sci. Soc. Amer. Proc. 15:84-9.

COLE, C. V., S. D. OLSEN, AND C. O. SCOTT.

1953. The nature of phosphate sorption by calcium carbonate. Soil Sci. Soc. Amer. Proc. 17:352-6.

DE BOER, J. H.

1950. Atomic forces and adsorption. Advances in Colloid Sci. 3:1-66.

DE HAAN, F. A. M.

1965. The interaction of certain inorganic anions with clays and soils. State Agric. Univ., Wageningen. Agric. Res. Rep. 655.

DEAN, L. A., AND E. J. RUBINS.

1947. Anion exchange in soils. I. Exchangeable phosphorus and the anion exchange capacity. Soil Sci. 63:377-87.

DEB, D., AND N. P. DATTA.

1967. Effect of associating ions on phosphorus retention in soil. 2. Under variable anion concentration. Plant Soil 26:432-44.

DESHPANDE, T. L., D. J. GREENLAND, ANDJ. P. QUIRK.

1968. Changes in soil properties associated with the removal of iron and aluminum oxides. J. Soil Sci. 19:108-23.

ELLIS, B. G.

1973. The soil as a chemical filter. In Recycling Municipal Wastewater and Sludge through Forest and Cropland. (W. E. Sopper and L. T. Kardos, eds.). pp. 46-70. Pennsylvania State Univ. Press, University Park, PA.

ENFIELD, C. G

1974. Rate of phosphorus sorption by five Oklahoma soils. Soil Sci. Soc. Amer. Proc. 38:404-7.

ENFIELD, C. G., AND B. E. BLEDSOE.

1973. Kinetic model for orthophosphate reactions in mineral soils. EPA-660/2-75-022. U. S. Government Printing Office, Washington, D.C. 20402.

ENFIELD, C. G., AND D. C. SHEW.

1975. Comparison of two predictive non-equilibrium models for phosphorus sorption and movement through homogeneous soils. J. Environ. Quality 4: 198-202.

ENFIELD, C. G., C. C. HARLIN, JR., AND B. E. BLEDSOE.

1976. Comparison of five kinetic models for orthophosphate reactions in mineral soils. Soil Sci. Soc. Amer. J. 40:243-49.

EVANS, T. D., ANDJ. K. SYERS.

1971. Application of autoradiography to study the fate of ${ }^{33} \mathrm{P}$ labeled orthophosphate added to soil crumbs. Soil Sci. Soc. Amer. Proc. 35:906-9.

FITTER, A. H., AND C. D. SUTTON.

1975. The use of the Freundlich isotherm for soil phosphate sorption data. J. Soil Sci. 26:241-6.

FORD, M. C.

1933. The nature of phosphate fixation in soils. J. Amer. Soc. Agron. 25:134-44.

FOX, R. L., ANDE. J. KAMPRATH.

1972. Phosphate sorption isotherms for evaluating the phosphate requirements of soils. Soil Sci. Soc. Amer. Proc. 34:902-7.

GARDNER, W. R.

1965. Movement of nitrogen in soil. In Soil Nitrogen, W. V. Bartholomew and F. E. Clark (eds.). p. 550 72. Agron. Monographs No. 10. Amer. Soc. Agron. Madison, Wisconsin.

GARDNER, B.R., AND J.P. JONES

1973. Effects of temperature on phosphate sorption isotherms and phosphate desorption. Comm. Soil Sci. Plant Anal. 4:83-93.

GBUREK, J. W., AND W. R. HEALD.

1974. Soluble P output of an agricultural watershed in Pennsylvania. Water Resources Research 10:113-8. 
GILES, C. H.

1970. Interpretation and use of sorption isotherms. In Sorption and transport processes in soils. Soc. Chem. Ind. (Londón) Monograph 37:14-32.

GORE, A. J. P.

1968. The supply of six elements by rain to an upland peat area. J. Ecol. 56:483-95.

GRAHAM, D.

1953. The characterization of physical adsorption systems. I. The equilibrium function and the standard free energy of adsorption. J. Phys. Chem. 57:665-89.

GREENBERG, A. E., AND J. F. THOMAS

1954. Sewage effluent reclamation for industrial and agricultural use. Sewage and Ind. Wastes. 26:761-70.

GREENLAND, D. J., J. M. OADES, AND T. W. SHERWIN.

1968. Electron-microscope observations of iron oxides in some red soils. J. Soil Sci. 19:123-6.

GRIFFIN, R. A. ANDJ. J. JURINAK.

1973. Interaction of phosphate with calcite. Soil Sci. Soc. Amer. Proc. 37:847-850.

GUNARY, D.

1970. A new adsorption isotherm for phosphate in soil. J. Soil Sci. 21:72-7.

HARTER. R. D., AND B. B. FOSTER.

1976. Computer simulation of phosphorus movement through soils. Soil Sci. Soc. Amer. J. 40:239-42.

HASEMAN, J. F., E. H. BROWN, AND C. D. WHITT.

1950a. Some reactions of phosphate with clays and hydrous oxides of iron and aluminum. Soil Sci. 70:257-71

HASEMAN, J. F., J. R. LEHR, ANDJ. P. SMITH.

1950b. Mineralogical character of some iron and aluminum phosphates containing potassium and ammonium. Soil Sci. Soc. Amer. Proc. 15:76-84.

HAYES, F. R., J. A. MCCARTER, M. L. CAMERON, AND D. A. LIVINGSTONE.

1952. On the kinetics of phosphorus exchange in lakes. J. Ecol. 40:202-12.

HINGSTON, F. J., R. J. ATKINSON, A. M. POSNER, ANDJ. P. QUIRK.

1967. Specific adsorption of anions. Nature 215:1459-61.

HINGSTON, F. J., A. M. POSNER, AND J. P. QUIRK.

1968. Specific adsorption of anions on goethite. Trans. Ninth Intern. Cong. Soil Sci. Adelaide 1:669-78.

1972. Anion adsorption by goethite and gibbsite, I. The role of the proton in determining adsorption envelopes. J. Soil Sci. 23:177-92.

HOLFORD, I. C. R., AND G. E. G. MATTINGLY.

1975a. The high- and low-energy phosphate adsorbing surfaces in calcareous soils. J. Soil Sci. 26:407-17.

1975b. Phosphate sorption by Jurassic Oolitic limestones. Geoderma 13:257-64.

HOLFORD, I. C. R., R. W. H. WEDDERBURN, AND G. E. G. MATTINGLY.

1974. Langmuir two surface equation as a model for $P$ adsorption by soils. J. Soil Sci. 25:242-56.

HOLT, R. F., D. R. TIMMONS, AND J. J. LATTERELL.

1970. Accumulation of phosphate in water. J. Agri. Food Chem. 18:781-84.

HOOK, J. E., L. T. KARDOS, AND W. E. SOPPER.

1973. Effects of land disposal of wastewater on soil phosphorus relations. In Recycling Treated Municipal Wastewater and Sludge through Forest and Cropland (W. E. Sopper and L. T. Kardos, eds.). pp. 200-19. Pennsylvania State Univ. Press, University Park, PA.

HOPE, G. D., AND J. K. SYERS.

1976. Effects of solution: soil ratio on phosphate sorption by soils. J. Soil Sci. 27:301-6.

HSU, P. H., AND D. A. RENNIE.

1962. Reactions of phosphate in aluminum systems. I. Adsorption by X-ray amorphous "aluminum hydroxide"'. Can. J. Soil Sci. 42:197-209.

HSU, P. H.

1964. Adsorption of phosphate by aluminum and iron in soils. Soil Sci. Soc. Amer. Proc. 28:474-8.

HUFFMAN, E. O.

1969. Behavior of fertilizer phosphates. Trans. Ninth Intern. Congr. Soil Sci., Adelaide 2:745-54.

HUFFMAN, E. O., AND A. W. TAYLOR.

1963. The behavior of water soluble phosphate in soil. J. Agric. Food Chem. 11:182-7.

HUNTER, J. V., AND T. A. KOTALIK.

1976. Chemical and biological quality of treated sewage effluents. In Recycling Treated Municipal Wastewater and Sludge through Forest and Cropland. (W. E. Sopper and L. T. Kardos, eds.) pp. 6-25. Pennsylvania State Univ. Press, University Park, PA.

JACKSON, M. L.

1963. Interlayering of expansible layer silicates in soils by chemical weathering. Clays Clay Minerals 11:29-46.

JENSEN, H. E.

1971. Phosphate solubility in Danish soils equilibrated with solutions of differing phosphate concentrations. J. Soil Sci. 22:261-6.

JOHNSON, A. H., D. R. BOUDLIN, E. A. GOYETTE, AND A. M. HODGES

1976. Phosphorus loss by stream transport from a rural watershed: Quantities, processes and sources. J. Environ. Quality 5:148-57. 
JURY, W. A.

1975a. Solute travel-time estimates for tile-drained fields. I. Theory. Soil Sci. Soc. Amer. Proc. 39:1020-4.

1975b. Solute travel-time estimates for tile-drained fields. II. Application to experimental fields. Soil Sci. Soc. Amer. Proc. 39:1024-8.

JURY, W. A., W. R. GARDNER, P. G. SAFFIGNA, AND C. B. TANNER.

1976. Model for predicting simultaneous movement of nitrate and water through a loamy sand. Soil Sci. 122:36-43.

KAFKAFI, V., A. M. POSNER, ANDJ. P. QUIRK.

1967. Desorption of phosphate from kaolinite. Soil Sci. Soc. Amer. Proc. 31:248-53.

KARDOS, L. T., ANDJ. E. HOOK.

1976. Phosphorus balance in sewage effluent treated soils. J. Environ. Quality 5:87-90.

KHALID, R. A., W. H. PATRICK, JR., AND R. D. DELAUNE.

1977. Phosphorus sorption characteristics of flooded soils. Soil Sci. Soc. Amer. J. 41:305-10.

KIRBY, C. F.

1971. Sewage treatment farms. (Post-graduate course in Public Health Engineering). Sess. No. 12, Dept. Civil Eng., Univ. of Melbourne, Australia. 14 pp.

KIRKHAM, D.

1958. Seepage of steady rainfall through soil into drains. Trans. Am. Geophys. Union. 39:892-908.

KIRKMAN, J. H.

1973. Amorphous inorganic materials in three soils formed from loess. I. Application of selective dissolution techniques. New Zeal. J. Sci. 16:79-93.

KITTRICK, J. A., AND M. L. JACKSON.

1955a. Rate of phosphate reaction with soil minerals and electron microscope observations on the reaction mechanism. Soil Sci. Soc. Amer. Proc. 19:292-5.

1955b. The common ion effect on phosphate solubility. Soil Sci. 79:415-21.

KITTRICK, J. A., AND M. L. JACKSON.

1956. Electron microscope observation of the reaction of phosphate with minerals leading to a unified theory of phosphate fixation. J. Soil Sci. 7:81-9.

KUNISHI, H.M., A.W. TAYLOR, W.R. HEALD, W.J. GBUREK, AND R.N. WEAVER.

1972. Phosphate movement from an agricultural watershed during two rainstorm periods. J. Agri. Food Chem. 20:900-5.

KUO, S., AND E. G. LOTSE.

1974. Kinetics of phosphate adsorption and desorption by hematite and gibbsite. Soil Sci. 116:400-6.

KURTZ, L. T., E. E. DETURK, AND R. H. BRAY.

1946. Phosphate adsorption by Illinois soils. Soil Sci. 61:111-24.

KUTERA, J.

1975. Treatment and disposal of wastewaters of settlements in rural, agricultural and non-urban areas. Progress in Water Tech. 7:877-84.

LANGMUIR, I.

1918. The adsorption of gases on plane surfaces of glass, mica and platinum. J. Amer. Chem. Soc. 40:1361-403.

LARSEN, S.

1967. Soil Phosphorus. Adv. Agron. 19:151-210.

LARSEN, S., AND M. N. COURT.

1961. Soil phosphate solubility. Nature 189:164-5.

LARSEN, S. AND A.E. WIDDOWSON.

1970. Evidence of dicalcium phosphate precipitation in a calcareous soil. J. Soil Sci. 21:364-7.

1971. Aging of phosphate added to soil. J. Soil Sci. 22:5-7.

LARSON, J. E., R. LANGSTON, AND G. F. WARREN.

1958. Studies on the leaching of applied labeled phosphorus in organic soils. Soil Sci. Soc. Amer. Proc. 22:558-60.

LARSON, V., J. H. AXIEY, AND G. L. MILLER.

1974. Agricultural wastewater accommodation and utilization of various forages. Tech. Report No. 19. Univ. of Maryland Water Resources Res. Center, College Park, Md.

LAW, J. P., JR., R. E. THOMAS, AND L. H. MEYER.

1970. Cannery wastewater treatment by high-rate spray on grassland. J. Water Pollut. Control Fed. 42:1621-31.

LEAVER, J. P., AND E. W. RUSSELL.

1957. The reaction between phosphate and phosphate fixing soils. J. Soil Sci. 8:113-26.

LIN, PING-WHA.

1975. Wastewater treatment with calcium sulfate from sulfur dioxide removal from waste gas. J. Water Pollut. Control Fed. 47:2271-80.

LINDSAY, W. L.

1973. Inorganic reactions of sewage wastes with soils. In Recycling Municipal Sludges and Effluents on Land. Natl. Assoc. of State Univ. and Land Grant Colleges. Washington, D.C. 
LINDSAY, W. L., AND E. C. MORENO.

1960. Phosphate phase equilibria in soils. Soil Sci. Soc. Amer. Proc. 24:177-82.

LINDSAY, W. L., M. PEECH, ANDJ. S. CLARK.

1959. Solubility criteria for the existence of variscite in soils. Soil Sci. Soc. Amer. Proc. 23:357-60.

LINDSAY, W. L., A. W. FRAZIER, AND H. F. STEPHENSON.

1962. Identification of reaction products from some phosphate fertilizers in soils. Soil Sci. Soc. Amer. Proc. 26:446-52.

LOW, P. F., AND C. A. BLACK.

1947. Phosphate-induced decomposition of kaolinite. Soil Sci. Soc. Amer. Proc. 12:180-4.

MATTSON, S.

1927. Anionic and cationic adsorption by soil colloidal materials of varying $\mathrm{SiO}_{2} / \mathrm{Al}_{2} \mathrm{O}_{3}+\mathrm{Fe}_{2} \mathrm{O}_{3}$ ratio. Trans. First Intern. Cong. Soil Sci., Washington. Commission 2:199-211.

MCAULIFFE, C. D., N. S. HALL, L. A. DEAN, AND S. B. HENDRICKS.

1947. Exchange reactions between phosphates and soils: hydroxylic surfaces of soil minerals. Soil Sci. Soc. Amer. Proc. 12:119-23.

MCLAUGHLIN, J. R., J. C. RYDEN, ANDJ. K. SYERS.

1977. Development and evaluation of a kinetic model to describe phosphate sorption by hydrous ferric oxide gel. Geoderma 18:295-307.

MITCHELL, D., V., C. FARMER, AND W. J. HARDY.

1964. Amorphous inorganic materials in soils. Advan. Agron. 16:327-83.

MULJADI, D., A. M. POSNER, ANDJ. P. QUIRK.

1966. The mechanism of phosphate adsorption by kaolinite, gibbsite and pseudoboehmite. J. Soil Sci. $17: 212-47$.

MUNNS, D. N., AND R. L. FOX.

1976. The slow reaction which continues after phosphate adsorption: Kinetics and equilibrium in some tropical soils. Soil Sci. Soc. Amer. J. 40:46-51.

MURRMANN, R. P., AND F. R. KOUTZ.

1972. Role of soil chemical processes in reclamation of wastewater applied to land. Chapter 4 in Wastewater Management by Disposal on Land. Corps of Engineers, U.S. Army. Cold Regions Res. and Eng. Lab., Hannover, N. H.

MURRMANN, R. P., AND M. PEECH.

1968. Reaction products of applied phosphate in limed soils. Soil Sci. Soc. Amer. Proc. 32:493-6.

1969. Relative significance of labile and crystalline phosphates in soil. Soil Sci. 107:249-55.

NAGARAJAH, S., A. M. POSNER, ANDJ. P. QUIRK.

1968. Desorption of phosphate from kaolinite by citrate and bicarbonate. Soil Sci. Soc. Amer. Proc. 32:507-10.

1970. Competitive adsorption of phosphate with polygalacturonate and other organic anions on kaolinite and oxide surfaces. Nature 228:83-5.

NELIER, J. R.

1947. Mobility of phosphate in sandy soils. Soil Sci. Soc. Amer. Proc. (1946) 11:227-30.

NIELSEN, D. R., J. W. BIGGAR, AND K. T. ERH.

1973. Spatial variability of field-measured soil water properties. Hilgardia 42:215-59.

NOVAK, L. T., D. C. ADRIANO, G. A. COULMAN, AND D. B. SHAH.

1975. Phosphorus movement in soils: Theoretical aspects. J. Environ. Quality 4:93-9.

OLSEN, S. R.

1972. Micronutrient interactions. In Micronutrients in Agriculture. O. J. Mortvedt, P. M. Giordano and W. L. Lindsay, eds.). Soil Sci. Soc. Amer., Inc., Madison, Wisc.

OLSEN, S. R., AND F. S. WATANABE.

1957. A method to determine a phosphorus adsorption maximum of soils as measured by the Langmuir isotherm. Soil Sci. Soc. Amer. Proc. 21:144-9.

OZANNE, P. G.

1963. Some nutritional problems characteristic of sandy soils. Trans. Joint Meeting Comm. IV and V Intern. Soc. Soil Sci., New Zealand, 1962. p. 139-43.

PATRICK, W. H., JR., AND R. A. KHALID.

1974. Phosphate release and sorption by soils and sediments: Effect of aerobic and anaerobic conditions. Science 186:53-5.

PATRICK, W. H., JR., AND I. C. MAHAPATRA.

1968. Transformation and availability to rice of nitrogen and phosphorus in water-logged soils. Advan. Agron. 20:323-59.

PHILIP, J. R.

1957. The theory of infiltration: 1 . The infiltration equation and its significance. Soil Sci. 83:365-67.

PIERRE, W. M., AND F. W. PARKER.

1927. Soil phosphorus studies. II. The concentration of organic and inorganic phosphorus in the soil solution and soil extracts and the availability of organic phosphorus to plants. Soil Sci. 24:119-28.

POMEROY, L. R., E. E. SMITH, AND G. M. GRANT.

1965. The exchange of phosphate between estuarine waters and sediments. Limnol. Oceanog. 10:167-72. 
PONNAMPERUMA, F. N.

1972. The chemistry of submerged soils. Advan. Agron. 24:29-96.

POUND, C. E., AND R. W. CRITES.

1973. Characteristics of municipal effluents. In Recycling Municipal Sludges and Effluents on Land. pp. 49-61. Nat. Assoc. State Univ. and Land Grant Colleges, Washington, D.C.

PRATT, P. F., W. W. JONES, AND H. D. CHAPMAN.

1956. Changes in phosphorus in an irrigated soil during 28 years of differential fertilization. Soil Sci. 82:295-306.

PRATT, P. F., F. F. PETERSON, AND C. S. HOLZHEY.

1969. Qualitative mineralogy and chemical properties of a few soils from Sao Paulo, Brazil. Turrialba 19:491-96.

PRATT, P. F., J. E. WARNEKE, AND P. A. NASH.

1976. Sampling the unsaturated zone in irrigated field plots. Soil Sci. Soc. Amer. J. 40:277-79.

RAJAN, S. S. S.

1975a. Adsorption of divalent phosphate on hydrous aluminum oxide. Nature 253: 434-6.

1975b. Phosphate adsorption and the displacement of structural silicon in an allophanic clay. J. Soil Sci. 26:250-6.

1976. Changes in net surface charge of hydrous alumina with phosphate adsorption. Nature 262:45-6.

RAJAN, S. S. S., AND R. L. FOX.

1972. Phosphate adsorption by soils. I. Influence of time and ionic environment on phosphate adsorption. Comm. Soil Sci. Plant Anal. 3:493-504.

RAJAN, S. S. S., K. W. PERROTT, AND W. M. H. SAUNDERS.

1974. Identification of phosphate-reaction sites of hydrous alumina from proton consumption during phosphate adsorption at constant pH values. J. Soil Sci. 25:438-47.

RECHT, H. L., AND M. GHASSEMI.

1970. Kinetics and mechanism of precipitation and nature of precipitate obtained in phosphate removal from waste water using aluminum and iron (III) salts. Water Pollution Control Research Series 17010EK1 04/70. Federal Water Quality Administration, U.S. Dep. Interior, Washington, D.C.

RENNIE, D.A., AND R.B. MCKERCHER.

1959. Adsorption of phosphate by four Saskatchewan soils. Can. J. Soil Sci. 39:64-75.

RIBLE, J. M., P. A. NASH, P. F. PRATT, AND L. J. LUND.

1976. Sampling the unsaturated zone of irrigated lands for reliable estimates of nitrate. Soil Sci. Soc. Amer. J. 40:566-70.

ROSE, C. W.

1966. Agricultural Physics. p. 160-170 Commonwealth International Library, Pergamon Press, Oxford.

ROTH, C. B., M. L. JACKSON, ANDJ. K. SYERS.

1969. Deferration effect on structural ferrous-ferric iron ratio and CEC of vermiculites and soils. Clays Clay Minerals 17:253-64.

RYDEN, J. C. ANDJ. K. SYERS.

1975a. Charge relationships of phosphate sorption. Nature 255:51-3.

1975b. Use of tephra for the removal of dissolved inorganic phosphate from sewage effluent. New Zeal. J. Sci. 18:3-16.

1975c. Rationalization of ionic strength and cation effects on phosphate sorption by soils. J. Soil Sci. 26:395-406

1977a. Desorption and isotopic exchange relationships of phosphate sorbed by soils and hydrous ferric oxide gel. J. Soil Sci. 28:596-609.

1977b. Origin of the labile phosphate pool in soils. Soil Sci. 123:353-61.

RYDEN, J. C., J. K. SYERS, AND R. F. HARRIS.

1973. Phosphorus in runoff and streams. Advan. Agron. 25:1-41.

RYDEN, J. C., J. K. SYERS, AND P. E. H. GREGG.

1976. A new understanding of the nature and persistence of labile phosphate in soils: Implications to soil testing. Reviews in Rural Science, No. 3, University of New England Press: 55-59.

RYDEN, J. C., J. R. MCLAUGHLIN, ANDJ. K. SYERS.

1977a. Mechanisms of phosphate sorption by soils and hydrous ferric oxide gel. J. Soil Sci. 28:72-92.

RYDEN, J. C., J. R. MCLAUGHLIN, AND J. K. SYERS.

1977b. Time-dependent sorption of phosphate by soils and hydrous ferric oxides. J. Soil Sci. 28:585-95.

RYDEN, J. C., J. K. SYERS, ANDJ. R. MCLAUGHLIN.

1977c. Effects of ionic strength on chemisorption and potential-determining sorption of phosphate by soils. J. Soil Sci. 28:62-71.

RUSSELL, E. W.

1973. Soil conditions and plant growth (Tenth Edition). Longman Group Limited, London. p. 849.

RUSSELL, E. J., ANDJ. A. PRESCOTT.

1916. The reaction between dilute acids and the phosphorus components of soil. J. Agric. Sci. 8:65-110.

SAUNDERS, W. M. H.

1965. Phosphate retention by New Zealand soils and its relationship to free sesquioxides, organic matter and other soil properties. New Zeal. J. Agric. Res. 8:30-57. 
SAWHNEY, B. L.

1977. Predicting phosphate movement through soil columns. J. Environ. Qual. 6:86-89.

SAWYER, C. N.

1947. Fertilization of lakes by agricultural and urban drainage. J. New England Water Works Assoc. 61:109-27.

SCHNEIDER, I. F., AND A. E. ERICKSON.

1972. Soil limitations for disposal of municipal wastewaters. Mich. Agri. Exp. Sta. Res. Rpt. 195.

SCHWERTMANN, U.

1966. Inhibitory effect of soil organic matter on the crystallization of amorphous ferric hydroxide. Nature 212: 645-6.

SCHWERTMANN, U. AND H. KNITTEL

1973. Phosphate adsorption by some Bavarian soils. Zeit. Pflanzen. Bodenk. 134:43-52.

SHAH, D. B., G. A. COUlMAN, L. T. NOVAK, AND B. G. ElliS.

1975. A mathematical model for phosphorus movement in soils. J. Environ. Quality 4:87-92.

SHAPIRO, R. E., AND M. FRIED.

1959. Relative release and retentiveness of soil phosphates. Soil Sci. Soc. Amer. Proc. 23:195-8.

SHARPLEY, A. N., ANDJ. K. SYERS.

1976 Phosphorus transport in surface runoff as influenced by fertilizer and grazing cattle. New Zeal. J. Sci. 19:277-82.

SHARPLEY, A. N., R. W. TILLMAN, ANDJ. K. SYERS.

1976. Use of laboratory extraction data to predict losses of dissolved inorganic phosphate in surface runoff and tile drainage. J. Environ. Qual. 6:33-6.

SHEN, M. J., AND C. I. RICH.

1962. Aluminum fixation in montmorillonite. Soil Sci. Soc. Amer. Proc. 26:33-6.

SHUKLA, S. S., J. K. SYERS, J. D. H. WILLIAMS, D. E. ARMSTRONG, AND R. F. HARRIS.

1971. Sorption of inorganic phosphate by lake sediments. Soil Sci. Soc. Amer. Proc. 35:244-9.

SPANGLER, F. C., W. E. SLOEY, AND C. W. FETTER, JR.

1976. Wastewater treatment by natural and artificial marshes. EPA-600/2-76-207. National Technical Information Service, Springfield, Va.

SPENCER, W. F.

1957. Distribution and availability of phosphate added to Lakeland fine sand. Soil Sci. Soc. Amer. Proc. 21:141-4.

STETTLER, R.

1975. Elimination of phosphates by STEP in Neuchatel. Gas Wasser Abwasser 55:359-63.

SYERS, J. K., AND J. D. H. WILLIAMS.

1977. Phosphorus and arsenic in soils. In Soil Chemistry, J. M. Bremner and G. Chesters (eds.). Marcel Dekker (In press)

SYERS, J. K., T. D. EVANS, J. D. H. WILLIAMS, ANDJ. T. MURDOCK.

1971. Phosphate sorption parameters of representative soils from Rio Grande do Sul, Brazil. Soil Sci. $112: 267-75$.

SYERS, J. K., G. M. BROWMAN, G, W. SMILLIE, AND R. B. COREY.

1973a. Phosphate sorption by soils evaluated by the Langmuir adsorption equation. Soil Sci. Soc. Amer. Proc. 37:358-63.

SYERS, J. K., R. F. HARRIS, AND D. E. ARMSTRONG.

1973b. Phosphate chemistry in lake sediments. A review. J. Environ. Quality 2:1-14.

TALIBUDEEN, $\mathrm{O}$.

1974. The nutrient potential of soil. Soils Ferts. 37:41-5.

TAYLOR, A. W., AND E. L. GURNEY.

1962. Phosphate equilibria in an acid soil. J. Soil Sci. 13:187-97.

TAYLOR, A. W., AND E. L. GURNEY.

1965. The effect of time on the phosphate potential and resin extractable phosphate in five acid soils. Soil Sci. Soc. Amer. Proc. 29:482-3.

TAYLOR, A. W., AND H. M. KUNISHI.

1971. Phosphate equilibrium in stream sediment and soil in a watershed draining an agricultural region. J. Agric. Food Chem. 19:827-31.

1974. Soil adsorption of phosphates from waste water. In Factors Involved in Land Application of Agricultural and Municipal Wastes. ARS-USDA National Program Staff, Soil, Water and Air Sciences, Beltsville, Maryland 20705. p. 66-96.

TAYLOR, A. W., E. L. GURNEY, ANDJ. R. LEHR.

1963. Decay of phosphate fertilizer reaction products in an acid soil. Soil Sci. Soc. Amer Proc. 27:145-8.

TAYLOR, A. W., W. M. EDWARDS, AND E. C. SIMPSON.

1971. Nutrients in streams draining woodland and farmland near Coshocton, Ohio. Water Resources Res. Res. 7:81-9.

THOMAS, R. E.

1973. Fate of materials applied. In Proc. Conf. Land Disposal Municpal Effluents Sludges EPA-902/9-73001. p. 181-200. 
THOMAS, R. E., B. BLEDSOE, AND K. JACKSON.

1976. Overland flow treatment of raw wastewater with enhanced phosphorus removal. EPA-600/2-76-131. U.S. Government Printing Office, Washington, D.C., 20402.

TISDALE, S. L., AND W. L. NELSON.

1975. Soil Fertility and Fertilizers. (Third Edition). Macmillan Publishing Co., Inc., New York, N.Y. 10022. $694 \mathrm{pp}$

TWENEBOAH, C. K., D. J. GREENLAND, ANDJ. M. OADES.

1967. Changes in charge characteristics of soils after treatment with $0.5 \mathrm{M}$ calcium chloride at $\mathrm{pH} 1.5$. Aust. J. Soil Res. 5:247-62.

VEITH, J. A., AND G. SPOSITO.

1977a. Reactions of aluminosilicates, aluminum hydrous oxides and aluminum oxide with ophosphate: Formation of X-ray amorphous analogs of variscite and montebrasite. Soil Sci. Soc. Amer. J. 41: 870-876.

1977b. On the use of the Langmuir equation in the interpretation of adsorption phenomena. Soil Sci. Soc. Amer. J. 41:697-702.

VIJAYACHANDRAN, P. K., AND R. D. HARTER.

1975. Evaluation of phosphorus adsorption by a cross section of soil types. Soil Sci. 119:119-26.

WARRINGTON, $R$.

1968. On the part taken by oxide of iron and alumina in the adsorptive action of soils. J. Chem. Soc. 21: 1-19.

WHITE, E.

1972. The distribution and movement of reactive phosphorus through catchments under various land use. Proc. New Zeal. Ecol. Soc. 19:163-72.

WILD, A

1954. The concentration of phosphate in the soil solution. Trans. Fifth Intern. Cong. Soil Sci., Leopoldville 2:500-4

WILLIAMS, E. G., N. M. SCOTT, AND M. J. MCDONALD.

1958. Soil properties and phosphate sorption. J. Sci. Food Agr. 9:551-9.

WILLIAMS, J. D. H., J. K. SYERS, AND T. W. WALKER.

1967. Fractionation of soil inorganic phosphate by a modification of Chang and Jackson's procedure. Soil Sci. Soc. Amer. Proc. 31:736-9.

WILLIAMS, J. D. H., J. K. SYERS, R. F. HARRIS, AND D. E. ARMSTRONG.

1970. Adsorption and desorption of inorganic phosphorus by lake sediments in a $0.1 \mathrm{M} \mathrm{NaCl}$ system. Environ. Sci. Technol. 4:517-9.

WITHEE, L. V., AND R. ELLIS.

1965. Change of phosphate potentials of calcareous soils on adding phosphorus. Soil Sci. Soc. Amer.

YEE, W. C. Proc. 29:511-4.

1966. Selective removal of mixed phosphates by activated alumina. J. Amer. Water Works Assoc. 58: 239-47. 